\title{
FISCAL ADJUSTMENTS IN OECD \\ COUNTRIES: COMPOSITION AND \\ MACROECONOMIC EFFECTS
}

\author{
Alberto Alesina \\ Roberto Perotti \\ Working Paper 5730
NATIONAL BUREAU OF ECONOMIC RESEARCH
1050 Massachusetts Avenue
Cambridge, MA 02138
August 1996

This paper was written while Alesina was visiting the European Department. He wishes to thank Massimo Russo and the entire department for the hospitality. For very helpful comments, we wish to thank Massimo Russo, Michael Deppler, Alessandro Leipold, Alessandro Prati, Vito Tanzi, and participants in two seminars in the Department. This research is partially supported by an NSF grant. This paper is part of NBER's research program in Monetary Economics. Any opinions expressed are those of the authors and not those of the National Bureau of Economic Research.

(C) 1996 by Alberto Alesina and Roberto Perotti. All rights reserved. Short sections of text, not to exceed two paragraphs, may be quoted without explicit permission provided that full credit, including $(\mathcal{C}$ notice, is given to the source. 


\title{
FISCAL ADJUSTMENTS IN OECD COUNTRIES: COMPOSITION AND MACROECONOMIC EFFECTS
}

\begin{abstract}
This paper studies how the composition of fiscal adjustments influences their likelihood of "success," defined as a long lasting deficit reduction, and their macroeconomic consequences. We find that fiscal adjustments which rely primarily on spending cuts on transfers and the government wage bill have a better chance of being successful and are expansionary. On the contrary fiscal adjustments which rely primarily on tax increases and cuts in public investment tend not to last and are contractionary.
\end{abstract}

We discuss alternate explanations for these findings by studying both a full sample of OECD countries and by focusing on three case studies: Denmark, Ireland and Italy.

\author{
Alberto Alesina \\ Department of Economics \\ Harvard University \\ Cambridge, MA 02138 \\ and NBER \\ aalesina@imf.org
}

\author{
Roberto Perotti \\ Department of Economics \\ Columbia University \\ 420 West 118 th Street \\ New York, NY 10027
}




\section{Introduction}

In the last two decades the debt to GDP ratios of many OECD countries has increased to levels historically observed only in the aftermath of major wars, as Table 1 documents.

The policymakers of countries with fiscal problems face several critical questions: (i) how large should the fiscal adjustment be, (ii) should one cut expenditures or raise revenues and, more specifically, which components of spending and revenues should one adjust, (iii) will the fiscal consolidation last or will it be reversed and higher deficits will soon reappear, and, finally, (iv) will the fiscal adjustment cause a recession?

The purpose of this paper is to make progress, well beyond our initial results in Alesina and Perotti (1995a, 1996), toward answering these questions. The critical point which we stress in this paper is that all the above questions are deeply interconnected. For instance, the composition of the fiscal adjustment influences both the likelihood of achieving a permanent consolidation of the budget and the macroeconomic consequences of the fiscal consolidation.

We identify two different types of fiscal adjustments. "Type 1" relies primarily on expenditure cuts, and, in particular, on cuts in transfers, social securicy and government wages and employment. Tax increases are a small fraction of the total adjustment and, in particular, taxes on households are not raised at all or are even reduced. On the contrary "Type 2" adjustments rely mostly on broad based tax increases, and often the largest increases are on taxes on households and social security contributions. On the expenditure side almost all the cuts are on public investment, while government wages, employment, and transfers are completely untouched, or only slightly affected. We find that even when the two types of adjustments have the same size, in terms of reduction of primary deficits, Type 1 adjustments induce a more lasting consolidation of the budget and are expansionary, while Type 2 adjustments are soon reversed by further deteriorations of the budget and have contractionary consequences on the economy.

The reason why type 1 adjustments are more permanent is that they tackle the two items of the budget, government wages and welfare programs which have the strongest tendency to automatically increase, and, in fact, have been increasing in the last three decades as a share of total government spending. 1/ Concerning the macroeconomic consequences of the two types of adjustments, the literature, which we review below, has generally focused on credibility effects and wealth effects of fiscal adjustments on consumption. We also emphasize the effects of fiscal policy on unit labor costs and competitiveness. In fact, we suggest, although we

1) See Tanzi and Schuknecht (1995) for a discussion of the transformation of the composition of government budgets in OECD countries in the last century. 
Table 1. Public Debt in OECD Countries

\begin{tabular}{|c|c|c|c|c|}
\hline & 1965 & 1975 & 1990 & 1994 \\
\hline Australia & n.a. & n.a. & 23.5 & 36.1 \\
\hline Austria & 19.4 & 23.9 & 58.3 & 65.7 \\
\hline Belgium & 67.5 & 61.1 & 128.5 & 135.0 \\
\hline Canada & 58.8 & 43.1 & -73.1 & 95.6 \\
\hline Denmark & 11.3 & 11.9 & 68.0 & 81.1 \\
\hline Finland & 17.7 & 8.6 & 16.8 & 62.3 \\
\hline France & 53.11 & 41.1 & 43.4 & 54.7 \\
\hline Germany & 17.3 & 25.1 & 43.4 & 51.5 \\
\hline Greece & 14.1 & 22.4 & 77.7 & 119.0 \\
\hline Ireland & n.a. & 64.4 & 97.4 & 92.3 \\
\hline Italy & 35.4 & 60.4 & 106.4 & 123.9 \\
\hline Japan & 0.0 & 22.4 & 66.0 & 75.6 \\
\hline Netherlands & 52.2 & 41.4 & 78.8 & 79.1 \\
\hline Norway & $47.01 /$ & 44.7 & 32.5 & 43.5 \\
\hline Portugal & n.a. & n.a. & 68.6 & 70.5 \\
\hline Spain & n.a. & n.a. & 50.3 & 68.2 \\
\hline Sweden & 30.5 & 29.5 & 44.3 & 79.5 \\
\hline United Kingdom & $81.81 /$ & 63.7 & 39.3 & 54.5 \\
\hline United States & 52.1 & 42.7 & 55.7 & 63.0 \\
\hline
\end{tabular}

Source: OECD. Debt is gross as a share of GNP.

11970 . 
do not have definite evidence, that the unit labor cost channel may even be more empirically relevant than the wealth effects and credibility channels on consumption.

This paper is organized as follows. Section II critically reviews several theoretical arguments on the contractionary or expansionary effects of fiscal adjustments. Section III discusses problems of cyclical adjustments of fiscal variables, and presents the procedure which we use. Section IV presents the empirical evidence on fiscal adjustments in a sample of 20 OECD countries for the period 1960 to 1994. Section V analyzes three countries as examples of Type 1 and Type 2 adjustments; the cases are Ireland, Denmark and Italy. The last section concludes.

\section{Contractionary or Expansionary Fiscal Consolidations: The Theory}

\section{Keynesian effects}

The standard keynesian argument is that a fiscal contraction has a temporary contractionary effect through an aggregate demand channel, in a model with sticky prices and wages. A standard multiplier effect implies that spending cuts are more recessionary than tax increases.

\section{Expansionary effects of fiscal contractions: the demand side}

\section{a. Wealth effects on consumption}

A cut in government spending, if perceived as long lasting, implies a permanent reduction in the future tax burden of consumers, generating a positive wealth effect.

Even tax increases can have expansionary effects on consumption. Blanchard (1990) argues that a tax increase today can have expansionary effects if it generates the expectations of less dramatic and disruptive tax increases tomorrow. Also, by resolving uncertainty about the course of future fiscal policy it may reduce precautionary savings.

Blanchard's argument is an example of what Bertola and Drazen (1993) characterize as the "expectation view of fiscal policy." That is, in an intertemporal model of consumption behavior, the effects of current fiscal policy depend on what expectations it generates on the course of future fiscal policy. In their words "a policy innovation that would be contractionary in a static model may be expansionary if it induces sufficiently strong expectations of future policy changes in the opposite direction."

Bertola and Drazen (1993) consider a model where government spending follows a random walk with a positive drift and national income is (for simplicity) constant. Bertola and Drazen argue, realistically, that stabilizations often have a discrete character. That is, even if public debt accumulates rapidly, political constraints often delay the adoption of 
the appropriate stabilization policies. 1 However, because of the feasibility constraint, sooner or later a stabilization will have to occur. Call $g_{c}$ the ratio of government spending over GDP at which with probabilicy p a stabilization occurs, where "stabilization" is a sharp drop in spending. If the stabilization does not occur at $g_{c}$, then it will occur with certainty later, when spending over GDP reaches a much higher level $B$. At that point, spending is set below $g_{c}$ so that, again, with probability $p$ a stabilization. may again occur at $\mathrm{g}_{\mathrm{c}}$.

The model implies that at low levels of government spending, private consumption falls less than one-to-one with increases in government spending: this is because an increase in spending implies that a stabilization may come soon. Thus, higher government spending only partially crowds out private demand, a typical keynesian result, obtained in a fully neoclassical model. When the economy reaches $g_{c}$, if the stabilization occurs, private consumption jumps up reflecting the wealth effect or reduced expected future taxes. With probability $1-p$, however, the stabilization does not occur. In this case consumption jumps down because the public realizes that political constraints will delay the stabilization. Thus, a failed stabilization has a contractionary effect because it signals the lack of political commitment to a "serious" attempt at reducing spending.

Bertola and Drazen's point is consistent with arguments put forward by Giavazzi and Pagano (1996). They argue that large fiscal contractions can be expansionary precisely because they signal a permanent and decisive change in the stance of fiscal policy, while small adjustments may have the opposite effect for the opposite reason. The "small" adjustments in Giavazzi and Pagano's words can be interpreted as an example of the failed stabilization at trigger point $g_{c}$, using the terminology of Bertola and Drazen.

Sutherland (1995) considers the effects of a stabilization in a model where consumers have finite lives, as in Blanchard(1985). Each consumer faces a constant probability of death in every period of his life, thus the model does not imply Ricardian properties even with nondistortionary taxes and transfers. As in Bertola and Drazen (1993) the government is on an unstable fiscal path and a stabilization sooner or later has to occur. At Low level of debt the model displays keynesian features. This is because the stabilization is expected to occur in the distant future, when many of the current consumers will be dead. These consumers do not internalize fully the future increase in taxation. As debt increases, the model

1) For instance, Alesina and Drazen (1991) model this delay as a result of a war of attrition between groups disagreeing on how to share the burden of the stabilization, so that time is necessary to resolve the political stalemate. 
displays anti-keynesian features, namely an increase in the fiscal deficit is contractionary. This is because current consumers expect that a stabilization will occur relatively soon, when they are still alive.

One problem with the expectation view is that the critical variable driving the results is the effect of current policies on the public's expectation about future policy changes, a variable which is intrinsically not observable. A devil's advocate might argue that any behavior of private consumption following any type of fiscal policy can be rationalized by an appropriate assumption about what the current fiscal policy signals about the not observable future policies. For instance, a generally accepred assumption in this literature is that a large spending cut signals a permanent change in the stance of fiscal policy. However, one may argue just the opposite. Suppose that a large spending cut threatens the political survival of a government committed to fiscal austerity, than a spending cut which is too large may imply a future relaxation of fiscal policy following an electoral defeat of the current government. While we do not particularly subscribe to this argument, the point is that the expectation view suffer from an embarrassment of riches; namely, it is consistent with too many possible empirical observations.

A second channel for wealth effects arises from a fall in interest rates which may accompany a fiscal adjustment. Lower interest rates imply a higher market value of private wealth.

\section{b. Credibility effects}

A fiscal consolidation, particularly a strong one in a high debt country, may have important credibility effects on interest rates by reducing risk premia. The latter can be of two types: (i) inflation risk premia or (ii) default or consolidation risk premia. Default risk may be trivial for relatively low debt countries, but may become significant for high debt ones. 1

A decisive discrete change in the fiscal policy stance may have a significant credibility effect on interest rates which would crowd in private investment and consumption of durable foods. For instance Miller, Skidelsky, and Weller (1990) consider a model with a threshold above which the government is forced to impose a tax on bond holders. With random shocks on the level of debt, as the debt level approaches that threshold, the risk premium increases, leading to a fall in private demand. A decisive

1 For some empirical discussion of default risk premia in high debt OECD countries see Alesina, De Broek, Prati, and Tabellini (1992). They show that a rough measure of default risk is not influenced by the level of the debt/GDP ratio at low levels of debt, but it is affected by it at high levels of debt. 
stabilization which reduces the debt level well below the threshold, eliminates the risk premium, crowding in the components of private demand particularly sensitive to interest rates.

Along similar lines, Alesina, Prati, and Tabellini (1990) show that at high level of debt, particularly if the debt has short maturity, selffulfilling confidence crises may materialize. If a crisis occurs and the public is not willing to roll over the debt, the government is forced to tax bond holders or default. A reduction in the level of the debt, and a lengthening of its maturity, reduces the risk of confidence crises and thus the associates risk premia. This is a model which displays multiple equilibria for some levels of debt/GDP ratios. Thus, a fiscal adjustment which reduces the debt below the level where multiple equilibria are possible, may have large discrete effects on the risk premia.

As for the case of the "expectation theory" on consumption behavior, however, this argument also relies on a variable; namely, "credibility of the adjustment" which is ex ante not observable. That is, it is not a priori obvious what makes an adjustment credible or not. However, Giavazzi and Pagano (1990) in their study of the Danish and Irish stabilization in the eighties report some suggestive evidence in favor of both the expectation view and the credibility effects. They show that standard wealth effects on consumption, and real interest rate effects on investment are not sufficient to explain the consumption and investment growth in these two countries during their fiscal adjustment.

\section{c. Supply-side effects}

\section{(1) Labor supply: neoclassical effects}

While wealth effects on consumption from permanent reductions in government spending are expansionary on the demand side, the same wealth effects may reduce labor supply (Barro (1991). If both consumption and leisure are normal goods, a wealthier individual will want to consume more of both, therefore he will work less. In addition, the induced higher real wages by reducing Tobin' q may crowd out investment (Baxter and King $(1993))$.

The standard substitution effect suggests that tax increases should reduce work effort and labor supply. Higher labor income taxes reduce labor supply. Thus, a permanent spending cut financed by a tax cut has two opposite effects on labor supply. The wealth effect reduces it, the substitution effect increases it.

In the case of a temporary cut in government spending, the wealth effect should be small and the substitution effect relatively large. Thus for temporary spending cuts the substitution effect should predominate, for permanent spending cuts the wealth effect should dominate. However, Baxter and KIng (1993) argue that their simulation shows that the financing side of the government budget (i.e., how the spending cut is financed with or 
without distortionary taxes) is more important for its macroeconomic impact on supply than its duration. Empirically, however, both the wealth effect and the substitution effect on individual labor supply are likely to be small. IJ

\section{(2) Labor market structure}

While the effect of taxes on individual labor supply may be small, their effects on aggregate labor supply in unionized labor markets may be much larger. With unionized labor markets a permanent increase in labor taxation shifts the union's aggregate supply of labor because it decreases the after tax income of employed union members at any before tax wage. In other words, an increase in labor taxation leads the union to demand higher real wages to compensate for the decreased after tax income.

Building on work by Calmfors and Driffil (1988), Alesina and Perotti (1994) show that this effect depend on the structure of labor markets. The effect is weak in countries with decentralized labor markets (like the United States or (anada) and is also relatively weak in countries with highly centralized unions where highly union-government negotiations internalize the entire fiscal maneuver. That is, at the bargaining table centralized union will take into consideration the spending side of the government budget as well; thus, for instance, the union will internalize the effects of higher taxes on more public goods or higher transfers. On the contrary, the effect of labor taxation on unit labor cost is highest in countries were union are strong enough to pass on tax increases to wages but not encompassing enough to internalize the connection between taxes and benefits of the fiscal maneuver. For example, Alesina and Perotti (1994) calculate that in the countries in the intermediate group an increase of the income tax of 1 percent of GNP causes an increase in relative unit labor costs of about 2 percent.

In summary, according to this channel tax increase affects unit labor costs of firms, influencing their competitiveness.

\section{d. Why composition matters $2 /$}

The previous discussion has highlighted that tax increases or spending cuts may have very different effects. Several additional reasons suggest that even the composition of spending cuts may have important consequences on how permanent the fiscal adjustment is and on its macroeconomic consequences. One can identify at least three reasons why the composition of cuts may matter.

1/ See for instance Pencavel (1986). For a general treatment of the neoclassical approach to fiscal policy see Barro (1989).

2/ For a discussion of composition effects on fiscal adjustments see also Perotti (1996a). 
(i) Expectation effect: Different types of spending cuts may be more or less permanent by their nature. Consider two types of spending cuts of the same magnitude. The first one relies only on a reduction in public investment, for instance in maintenance of public infrastructures. The second one includes cuts in welfare obtained by changes in eligibility criteria for transfer programs and by cuts in government employment. Even though the two types of spending cuts may have the same "impact" magnitude, clearly the second one has more lasting effects than the first. In fact maintenance of public infrastructure cannot be postponed forever; on the contrary, structural changes in the parameters which determine the extent of the coverage of the "welfare state" by influencing the dynamic of entitlement have long lasting effects. Thus, according to this argument, the composition, much more than the size per se, influences expectations about future the future stance of fiscal policy, a critical point of the expectation view.

(ii) Political credibility effect: Governments which are willing to tackle the politically more delicate components of the budgets, public employment, social security, welfare programs, may signal that they are really "serious" about the fiscal adjustment. Not every government has the necessary strength to tackle these politically difficult issues. Typically, coalition governments lack the necessary cohesion to implement this type of adjustment, as shown by Alesina and Perotti (1995a). I/ In fact, coalition governments succumb to intercoalition conflicts concerning the distributional consequences of the adjustment. $2 /$ On the contrary, single party governments may have the necessary strength to cut transfers, social security programs, and the government wage bill. 3 /

(iii) Labor market effect: Cuts in the government wage bill may have different effects than cuts in non wage government consumption. Lane and Perotti (1996) show that a fall in government employment shifts the aggregate demand for labor facing the union, thus improving profitability through two channels: a fall in unit labor costs, and a depreciation of the exchange rate in a flexible exchange system. On the contrary, a cut in nonwage government consumption does not have these effects because, at least up to a first degree of approximation, the private and the public sectors have the same propensity to spend on the goods and services which enter in the definition of nonwage government consumption. They present empirical

1) This result is consistent with previous empirical results by Roubini and Sachs (1989) and Grilli, Masciandaro, and Tabellini (1990) which suggest that coalition governments are less fiscally responsible.

2/ A model of "war of attrition" among coalition members may rationalize this effect; see Alesina and Drazen (1991) and Spolaore (1993). For a similar argument based upon a "tragedy of the common" game see velasco (1994).

3/ According to the results by Alesina and Perotti (1995a) both left leaning and right leaning governments have been able in about equal proportion to achieve successful fiscal stabilization. 
evidence on a sample of OECD countries which shows that the composition of spending cuts strongly influences labor market variables, in the direction described above.

The composition of tax increases may also influence the macroeconomic consequences of fiscal adjustment. For instance, Alesina and Perotti (1994 and 1995b) show that taxes on household and social security contributions have the largest impact on relative unit labor costs, via union behavior.

\section{Fiscal Impulse: Cyclical Adjustment}

We are interested in discretionary changes in the fiscal position of a country. Thus we need a measure of a fiscal impulse, defined the discretionary change in the government budget balance. For this reason we focus upon primary deficits rather than total deficits, since fluctuations in interest payments cannot be considered discretionary, unless extraordinary measures (default, consolidation) are taken.

The second, more difficult, issue concerns the cyclical correction. One need to isolate the discretionary change in the primary deficit, defined as the difference between the actual change in the deficit and the change that would have occurred, had the policymakers done nothing. Clearly the problem is to define what doing nothing means. For instance it may mean that certain spending programs remain constant in nominal terms at last year level, or constant in real terms, or constant in share of GDP, etc. The following brief discussion highlights some possible methodologies: it goes beyond the scope of the present paper to provide a comprehensive discussion of the issue of cyclical adjustment. 1/

The simplest approach to cyclical corrections, is simply to ignore the problem and just consider changes in the primary balance as a measure of fiscal impulse. The great advantage of this measure is its simplicity and transparency. Its disadvancage, of course, is that it ignores the effects on the budget of cyclical fluctuations of growth and unemployment.

A second measure, typically used by the OECD, defines the fiscal impulse as the difference between the current primary deficit and the primary deficit which would have prevailed if expenditures in the previous year had grown with potential GDP and revenues with actual GDP. This approach relies on potentially questionable measures of potential output.

A third measure, used by the IMF, is similar to the OECD one but assumes as a benchmark year not the previous one but a reference year when output was supposed to be at its potential level.

1/ For overviews see Mckenzie (1989), and Perotti (1996b). 
In this paper, as in Alesina and Perotti (1995a) we use a fourth measure proposed by Blanchard (1993), which maintains much simplicity and transparency, while, at the same time, provides an attractive cyclical correction. Essentially this measure implies a calculation of how the government budget would be if unemployment had not changed from the previous year. Specifically, this cyclical adjustment is an attempt at eliminating from the budget changes in taxes and transfer associated with changes in the unemployment rate.

There is no perfect cyclical correction, and in fact different approaches may lead to non trivial or even systematic differences. For example, Perotti (1996b) compares the OECD measure and the Blanchard measure and concludes that the OECD measure systematically overestimate the amount of discretionary component relative to the Blanchard measure when the deficit falls, and underestimates the amount of discretionary component when the deficit increases. This author also shows that the differences in the two measures ar far from trivial in certain cases.

We use a simple implementation of the Blanchard's measure constructed as follows: for each councry we regress transfers as a share of GDP (TRANSF) on two time trends $(1960-75)$ and $(1976-94)$ and the unemployment rate (U).

$$
\text { TRANSF }_{t}-a_{0}+a_{1} \text { TREND1 }+a_{2} \text { TREND2 }+a_{3} U_{t}+\epsilon_{t}
$$

Define $\hat{a}_{0}, \hat{a}_{1}, \hat{a}_{2}$, and $\hat{a}_{3}$ the estimated parameters of equation (1) and $\hat{\epsilon}_{t}$ the estimated residual. We then compute what the variable TRANSF would have been in period $t$, if the unemployment rate had remained constant between $(t-I)$ and $t$ :

$$
\operatorname{TRANSF}_{t}\left(U_{t-1}\right)=\hat{a}_{0}+\hat{a}_{1} \operatorname{TREND} 1+\hat{a}_{2} \operatorname{TREND} 2+\hat{a}_{3} U_{t-1}+\hat{\epsilon}_{t}
$$

We follow the same procedure to adjust tax revenues, defined as $T_{t}\left(U_{t-1}\right)$. Using TRANSF $F_{t-1}\left(U_{t}\right)$, together with all the other components of spending and $T_{t}\left(U_{t-1}\right)$, we compute our measure of cyclically adjusted primary deficits. 1/ Our measure of the fiscal impulse is then constructed as the difference between the cyclically adjusted primary deficit in period $t$ and the same variable in period $t-1$, all in shares of GDP. We sometimes refer to this fiscal impulse variable as "BFI", for "Blanchard Fiscal Impulse."

Several reasons justify our choice for a cyclical correction. First, we find its simplicity attractive. This measure does not rely on possibly questionable and sometimes obscure measures of potential output or base years. Second, this simplicity does not come at a high price for us. In fact, since our focus is on large changes in the fiscal stance, cyclical factors typically should not play a major role. Clearly, one can think of exceptional circumstances when major exogenous shocks have caused large

1/ See the appendix in Alesina and Perotti (1995a) for details. 
changes in budget deficits, but these are probably the exception more than the rule. Third, current work by McDertmott and Wescott (1996) pursuing a similar research strategy to ours, adopts the OECD cyclical correction, therefore it is useful to use a different approach to check on the robustness of results. Finally, sensitivity analysis using different cyclical corrections suggests that the qualitative nature of our result is quite robust.

\section{Fiscal Adjustments in OECD Countries}

\section{Definitions, sample, and basic statistics}

We consider a sample of 20 OECD countries for the period 1960 to 1994. The countries are: Australia, Austria, Belgium, Canada, Denmark, Finland, France, Germany, Greece, Ireland, Italy Japan, Netherlands, Norway, Portugal, Spain, Sweden, Switzerland, United Kingdom, and United States. Our definition of "government" is general government, as defined by the OECD which is our data source. We have 378 usable observations. We have excluded all the country-years for which a complete set of data needed for our tests was not available.

We focus upon periods of very tight fiscal policy. In particular, we consider relatively large budget adjustments, for two reasons. First, by considering large policy changes, we are less likely to be unduly influenced by cyclical factors. Second, macroeconomic and composition effects are more likely to be detectable in the case of large adjustments. We use the following definition of a tight fiscal policy:

Definition 1: A period of tight fiscal policy is a year when BFI falls by more than 1.5 per cent of GDP or a period of two consecutive years in which BFI falls by at least 1.25 per cent per year in both years.

This definition allows for both a yearly definition of an adjustment and two-year definition. In Alesina and Perotti (1995a) we considered only "one year" adjustments. That procedure implies counting as several different adjustments, a sequence of a multiyear adjustment program. In Alesina and Perotti (1996) we considered a few multiyear cases. With this two-year definition we strike a balance between the two. While there is a certain degree of arbitrariness in this choice, like in any alternative, we show below, by reviewing related literature and performing sensitivity cests, that the nature of our results is not unduly sensitive to this particular definition.

Table 2 shows that, on average, the fiscal impulse is close to zero. However this is the result of significant increases in primary expenditures and revenues, of more than 0.3 percent of GDP per year. This observation reflects the well-known "growth of government" occurred in the last several decades in OECD countries. In our sample we have 62 years of tight fiscal 
policy, with an average improvement in the BFI of more than 2.5 per cent of GDP. This reduction in deficits is about equally distributed between higher taxes and lower spending.

Table 2. Tight Fiscal Policy: Primary Expenditures and Revenues 1

\begin{tabular}{lcccc}
\hline & $\begin{array}{c}\text { Number of } \\
\text { Observations }\end{array}$ & $\begin{array}{l}\text { Fiscal } \\
\text { Impulse }\end{array}$ & $\begin{array}{c}\text { Primary } \\
\text { Expenditures }\end{array}$ & Revenues \\
\hline All sample & 378 & -0.07 & 0.32 & 0.38 \\
& 62 & $(0.09)$ & $(0.09)$ & $(0.06)$ \\
Tight & 62.57 & -1.34 & 1.22 \\
& & $(0.20)$ & $(0.23)$ & $(0.15)$ \\
\hline
\end{tabular}

Source: OECD.

1) All the variables are in changes of ratios over GDP. Standard deviations in parentheses.

We now need a definition of "success."

Definition 2: A period of tight fiscal policy is successful if one of the two following conditions applies: (i) in the three years after the tight period the ratio of the cyclically adjusted primary deficit over GDP is on average at least 2 percent of GDP below the last year of the tight period; (ii) three years after the last year of the tight period the debt to GDP ratio is 5 percent of GDP below the level of the last year of the tight period.

This definition allows for both a measure of success on the stock of debt and a measure on the flow of cyclically adjusted primary deficits. This definition is quite demanding, nevertheless about a fourth of tight policies are successful. Table 3 lists all the cases of successful adjustments: we have 13 episodes, for a total of 16 observation/years. As we 
discuss below our results are not unduly sensitive to reasonable changes in this definition. In particular, we illustrate below results obtained with a much more lenient definition of success. 1/

Table 3. Successful Fiscal Adjustments $1 /$

$\begin{array}{lll}\text { Austria } & 1987 & \\ \text { Denmark } & 1984 & \text { (2 years) } \\ \text { United Kingdom } & 1977 & \\ \text { Ireland } & 1988 & \text { (2 years) } \\ \text { Ireland } & 1989 & \text { (2 years) } \\ \text { Norway } & 1980 & \\ \text { Portugal } & 1977 & \\ \text { Portugal } & 1982 & \\ \text { Sweden } & 1984 & \text { (2 years) } \\ \text { Sweden } & 1987 & \text { (2 years) } \\ \text { United States } & 1976 & \end{array}$

1 For cases of two-year adjustments we indicate the second year.

\section{Success and composition}

Table 4 shows that successful adjustments are slightly larger in terms of fiscal impulse than unsuccessful ones: the difference is about 0.5 of GDP. While this difference is not trivial, more striking differences appear in the composition. In successful cases (16 observation years) about 73 percent of the adjustment is on the spending side; in unsuccessful cases ( 46 observation years) about 44 percent of the adjustment is on the expenditure side.

Even more striking are the differences in composition of different types of spending and sources of revenue. Tables 5 and 6 consider a breakdown of the spending side in its major components. In unsuccessful cases more than two thirds of the cuts are on capital spending while everything else, particularly government wages, are virtually untouched. In successful cases cuts in capital expenditures are actually much lower in

1/ One may argue that a definition of success should allow for difference across countries based upon initial conditions. However, one would make the data coo diffuse and impossible to analyze by allowing for different definitions of success for different initial conditions. We leave this problem to future research. 
term of GDP share than in unsuccessful cases, despite the larger amount of total spending cuts. In fact, only one fifth of total spending cuts in successful cases are on public investment. The critical difference is that in successful adjustments the largest cuts are on transfers and government wages, which together are almost 60 percent of the total spending cuts. In successful adjustments transfer and government wages are reduced by almost 1.2 percent of GDP per year, while in unsuccessful cases the sum of these two components is less than 0.2 percent of GDP per year.

Table 4. Successful and Unsuccessful Adjustments:

Expenditures and Revenues 1/

$\begin{array}{clcc}\text { Number of } & \text { Fiscal } & \text { Primary } & \\ \text { Observations } & \text { Impulse } & \text { Expenditures } & \text { Revenues }\end{array}$

Successful adjustments

Unsuccessful adjustments
16

46

$$
-2.92
$$$$
\text { (0.28) }
$$

$-2.44$

(0.24)

$$
-2.12
$$

$(0.29)$

0.83

$(0.36)$

\author{
n
}


Tabla 5. Successful and Unsuccessful Adjustnents: Camposition of Expenditure Cuts 1/

\begin{tabular}{|c|c|c|c|c|c|c|c|}
\hline & $\begin{array}{c}\text { Number of } \\
\text { Observations }\end{array}$ & $\begin{array}{c}\text { Primary } \\
\text { Expenditures }\end{array}$ & $\begin{array}{c}\text { Public } \\
\text { Investment }\end{array}$ & Iransfers & $\begin{array}{l}\text { Vermment } \\
\text { Wages }\end{array}$ & $\begin{array}{l}\text { Nonwaga Public } \\
\text { Consumption }\end{array}$ & Subsidies \\
\hline Successful adjustments & 16 & $\begin{array}{l}-2.12 \\
(0.29)\end{array}$ & $\begin{array}{l}-0.43 \\
(0.16)\end{array}$ & $\begin{array}{l}-0.48 \\
(0.18)\end{array}$ & $\begin{array}{l}-0.58 \\
(0.08)\end{array}$ & $\begin{array}{l}-0.30 \\
(0.06)\end{array}$ & $\begin{array}{l}-0.27 \\
(0.18)\end{array}$ \\
\hline Unsuccessful adjustments & 46 & $\begin{array}{l}-1.07 \\
(0.29)\end{array}$ & $\begin{array}{l}-0.68 \\
(0.30)\end{array}$ & $\begin{array}{l}-0.14 \\
(0.08)\end{array}$ & $\begin{array}{l}-0.05 \\
(0.06)\end{array}$ & $\begin{array}{l}-0.06 \\
(0.03)\end{array}$ & $\begin{array}{l}-0.08 \\
(0.05)\end{array}$ \\
\hline
\end{tabular}

Source: OECD. Seg Appendix for a precise definition of variables.

1/ All variables are in changes of ratios over GDR. Standard deviations in parentheses.

Tabla 6. Successful and Unsuceessful Adjustments: Composition of Expenditura Cuts as Shares of Total Expenditure Cuts

\begin{tabular}{|c|c|c|c|c|c|c|c|}
\hline & $\begin{array}{l}\text { Number of } \\
\text { Observations }\end{array}$ & $\begin{array}{c}\text { Publie } \\
\text { Investment } \\
\text { (1) }\end{array}$ & $\begin{array}{c}\text { Iransfors } \\
\text { (2) }\end{array}$ & $\begin{array}{c}\text { Govermment } \\
\text { Wages } \\
\text { (3) }\end{array}$ & $\begin{array}{l}\text { Colums } \\
(2)+(3)\end{array}$ & $\begin{array}{l}\text { Nonwage Govt. } \\
\text { Consunption } \\
\text { (4) }\end{array}$ & $\begin{array}{c}\text { Subsidias } \\
\text { (5) }\end{array}$ \\
\hline Successful adjustrents & 16 & $\begin{array}{l}-0.20 \\
(0.07)\end{array}$ & $\begin{array}{l}-0.23 \\
(0.09)\end{array}$ & $\begin{array}{l}-0.28 \\
(0.04)\end{array}$ & -0.51 & $\begin{array}{l}-0.14 \\
(0.03)\end{array}$ & $\begin{array}{l}-0.13 \\
(0.08)\end{array}$ \\
\hline Unsuccessful adfustments & 46 & $\begin{array}{l}-0.63 \\
(0.28)\end{array}$ & $\begin{array}{l}-0.13 \\
(0.07)\end{array}$ & $\begin{array}{l}-0.04 \\
(0.05)\end{array}$ & -0.17 & $\begin{array}{l}-0.06 \\
(0.03)\end{array}$ & $\begin{array}{l}-0.07 \\
(0.05)\end{array}$ \\
\hline
\end{tabular}

Source: OECD. Computations from Table 5. Standard deviations in parentheses. 
Cuts in the government wage bill may arise from lower wages and from lower employment. Table 7 considers government employment. This table shows that while during successful adjustments the growth of government employment significantly drops, during unsuccessful adjustments the rate of growth of the same variable is about the same as before and after. These observations hold both for government employment alone for the same variable as a share of the labor force.

In other words, Tables 5, 6, and 7 paint the following picture: Successful adjustments are based on broad-based spending cuts which do not spare the most politically sensitive parts of the budget; namely, transfers, social security and government wages and employment, which in fact receive the largest share of expenditure reductions. On the contrary, unsuccessful adjustments concentrate most of their cuts on capital expenditures, probably for two reasons. First, the effects of cuts in public investment, such as postponing maintenance of infrastructure or delaying new capital projects is less immediately visible to voters than cuts in their salaries or pensions checks. 1/ Second, "creative accounting" is probably easier in the capital accounts. $\underline{2}$

Tables 8 and 9 display the composition of tax increases. In successful adjustments tax increases are concentrated on business and on indirect taxes. The increase in business taxes may be due to a larger base rather than to higher rates. In fact, we show below that the profit share tends to increase in successful adjustments. Taxes on households do not increase at all and social security contributions are also spared almost completely. On the contrary the tax increase of unsuccessful adjustments are widely spread on all components. The contrast between cases of success and failure is particularly striking for taxes on households and social security. The total share of tax increases of these two components is about 90 percent in successful cases and less than 45 percent in unsuccessful cases. As shown in Alesina and Perotti (1994 and 1995b) and discussed above, these two types of taxes, on households, and social security contributions, have the strongest effects on unit labor costs, via union behavior. As we show in the next subsection, the pattern of unit labor costs is, in fact, very

1/ See Rogoff (1990) for an insightful discussion of political cycles on the budget composition, where opportunistic policymakers cut public investment before elections because they are less visible to voters than transfers.

2) See our discussion on Italy below, Tanzi (1994), and Alesina, Marè, and Perotti (1996). 
different in successful versus unsuccessful adjustments, and may contribute to explain difference in the macroeconomic consequences of fiscal

adjus tments.

Table 7. Government Employment in Successful and Unsuccessful Adjustments 1 /

\begin{tabular}{|c|c|c|c|c|c|c|}
\hline & \multicolumn{3}{|c|}{ Successful } & \multicolumn{3}{|c|}{ Unsuccessful } \\
\hline & Before & During & After & Before & During & After \\
\hline $\begin{array}{l}\text { Rate of growth of } \\
\text { govt. employment }\end{array}$ & $\begin{array}{l}3.01 \\
(0.36)\end{array}$ & $\begin{array}{c}0.91 \\
(0.79)\end{array}$ & $\begin{array}{l}2.52 \\
(1.19)\end{array}$ & $\begin{array}{c}2.81 \\
(0.40)\end{array}$ & $\begin{array}{c}2.18 \\
(0.32)\end{array}$ & $\begin{array}{r}2.32 \\
(0.46\end{array}$ \\
\hline $\begin{array}{l}\text { Rate of growth of } \\
\text { govt. employment } \\
\text { over total labor } \\
\text { force }\end{array}$ & $\begin{array}{l}1.41 \\
(0.34)\end{array}$ & $\begin{array}{c}0.29 \\
(0.65)\end{array}$ & $\begin{array}{c}1.04 \\
(1.04)\end{array}$ & $\begin{array}{l}1.79 \\
(0.38)\end{array}$ & $\begin{array}{c}1.22 \\
(0.27)\end{array}$ & $\begin{array}{r}1.34 \\
(0.24\end{array}$ \\
\hline
\end{tabular}

Source: OECD.

1) "Before" is the yearly average of the two-year before the fiscal adjustment; "during" is the one-year or yearly average of the two-year adjustment period; "after" is the yearly average of the two-year period after the adjustment. Standard deviations in parentheses.

Tabla a. Successful and Unsuccessful Adjustmenta:

Composition of Increases in Revenues

\begin{tabular}{|c|c|c|c|c|c|c|}
\hline & $\begin{array}{l}\text { Number } \\
\text { of Obs }\end{array}$ & Revenues & $\begin{array}{l}\text { Taxes on } \\
\text { Eougeholds }\end{array}$ & $\begin{array}{l}\text { Tares on } \\
\text { Busingas }\end{array}$ & $\begin{array}{l}\text { Indirect } \\
\text { Taxes }\end{array}$ & $\begin{array}{l}\text { Social Security } \\
\text { Contributions }\end{array}$ \\
\hline Successful & 16 & 0.83 & 0.00 & 0.51 & 0.20 & 0.09 \\
\hline adjus tments & & $(0.36)$ & $(0.23)$ & $(0.22)$ & $(0.12)$ & $(0.19$ \\
\hline Unsuccessful & 46 & 1.36 & 0.35 & 0.29 & 0.43 & 0.31 \\
\hline adjus tments & & $(0.16)$ & $(0.09)$ & $(0.09)$ & $(0.08)$ & 10.09 \\
\hline
\end{tabular}

Source: OECD. See Appendix for a more precise definition of all variablea. Standard devlations in parentheses. 
Table 9. Successful and Unsuccessful Adjustronts: Composition of Iax Increases as a Share of Total Tax Increases

\begin{tabular}{|c|c|c|c|c|c|}
\hline & $\begin{array}{c}\text { Number of } \\
\text { Observations }\end{array}$ & $\begin{array}{c}\text { Taxes on } \\
\text { Eouseholds }\end{array}$ & $\begin{array}{l}\text { Taxes on } \\
\text { Business }\end{array}$ & $\begin{array}{c}\text { Indirect } \\
\text { Taxes }\end{array}$ & $\begin{array}{l}\text { Social Security } \\
\text { Contzibutions }\end{array}$ \\
\hline Successful & 16 & 0.00 & 0.62 & 0.24 & 0.10 \\
\hline adjustments & & $(0.27)$ & $(0.26)$ & $(0.14)$ & $(0.23$ \\
\hline Unsuccassful & 46 & 0.25 & 0.21 & 0.32 & 0.23 \\
\hline adjustments & & $(0.07)$ & $(0.06)$ & $(0.06)$ & $(0.07$ \\
\hline
\end{tabular}

Source: OECD. Computations from Table a. Standard deviations in parentheses.

\section{Macroeconomic consequences of fiscal adjustments}

Table 10 sumarizes some basic statistics before, during, and in the immediate aftermath of successful and unsuccessful adjustments. The term "before" refers to the two-year period before the beginning of the tight policy. The term "after" refers to the two-year period after the last year of the tight fiscal policy. The term "during" is the year or the two-year period of the fiscal adjustment. All the variables in the table are yearly averages.

The rate of GDP growth, measured in differences from the G-7 average (for obvious reasons) shows large differences between successful and unsuccessful cases. During successful adjustments growth is more than 1 percent above G-7 average and this difference is statistically significant; afterward, growth falls but it still above G-7 average. On the contrary, during and after unsuccessful adjustments growth remains below G-7 average. Interestingly, before successful adjustments growth is not higher (relative to G-7) than before unsuccessful adjustments; in fact it is slightly lower. This observation suggests adjustments are not successful simply because they are started in a period of high growth.

Unemployment relative to G-7 after a successful adjustment is at about the same level as before it. After an unsuccessful one, unemployment relative to $G-7$ has doubled, from less than 1 percent above $G-7$ average to almost 2 percent above the same average.

The rate of growth of private investment shows a sizable difference between the two types of adjustments. An investment boom occurs during and after the successful adjustments. In unsuccessful cases the rate of growth of investment falls during and after the adjustment, relative to before and it is much lower than in successful cases. The cumulative growth rate of investment during and after successful adjustments is about 25 percent, 
while it is only about 8 percent during and after unsuccessful cases. The rate of growth of consumption does not show large differences between the two types of adjustments. These last two observations are intriguing, since the academic literature (theoretical and empirical) has typically focused on consumption much more than on investment.

Nominal and ex post real long interest rates, relative to G-7, do not show strong differences between the two types of adjustments, although nominal rates do fall during successful adjustments relative to before, and, instead, they increase during unsuccessful ones.

Very interesting observations emerge from the evidence on unit labor costs and measures of competitiveness. First of all, the data on relative unit labor costs show large differences between successful and unsuccessful cases. Relative unit labor costs significantly fall before and during successful cases while they are about constant in unsuccessful ones. The cumulative fall before and during successful cases is more than 10 percent.

The behavior of relative unit labor costs can be influenced by two factors: a depreciation of the nominal exchange rate in an economy with nominal rigidities, and a containment of wage pressure. As Table 10 shows, both successful and unsuccessful adjustments have been accompanied and preceded by nominal depreciations, somewhat larger in successful cases. However, significant depreciations accompanied unsuccessful adjustments as well. What is interesting is than while in successful cases the nominal depreciations had an impact on competitiveness (unit labor costs) in unsuccessful cases it did not. These observations suggest that the behavior of real wages is significantly different in the two types of adjustments. As argued above, this difference may be linked to the composition of the fiscal adjustment, and in particular to the difference in the behavior of government wages and employment and taxes on households and social security contributions. The evidence on the trade balance confirms the superior performance of net exports in successful versus unsuccessful adjustments.

The last three columns of Table 3 display an index of profitability and distributional shares. An index of the value added deflator over unit labor costs (VAULC) shows a rather different behavior in successful and unsuccessful adjustments. In the former group one observes a significant increase in this index of profitability during the adjustments, while in unsuccessful cases the same index is constant. The behavior of real wages, unit labor costs, and profitability also has clear implications on the distributional shares. While the wage share goes down by about 3 points, and the profit share increases by about 2 points during successful adjustments, these two shares are virtually constant in unsuccessful cases. 
Table 10. Successful and Unsucceseful Adjustments:

Macroeconomic Conditions 1

\begin{tabular}{|c|c|c|c|c|c|c|}
\hline & \multicolumn{3}{|c|}{ Successful } & \multicolumn{3}{|c|}{ Unsuceessful } \\
\hline & Before & During & After & Before & Durigg & After \\
\hline$G R(G-7)$ & $\begin{array}{l}-0.08 \\
(0.49)\end{array}$ & $\begin{array}{c}1.05 \\
(0.45)\end{array}$ & $\begin{array}{c}0.28 \\
(0.57)\end{array}$ & $\begin{array}{c}0.27 \\
(0.21)\end{array}$ & $\begin{array}{l}-0.29 \\
(0.34)\end{array}$ & $\begin{array}{l}-0.23 \\
(0.25)\end{array}$ \\
\hline$U(G-7)$ & $\begin{array}{c}1.20 \\
(1.09)\end{array}$ & $\begin{array}{c}1.44 \\
(1.36)\end{array}$ & $\begin{array}{c}1.08 \\
(0.93)\end{array}$ & $\begin{array}{c}0.82 \\
(0.44)\end{array}$ & $\begin{array}{c}1.49 \\
(0.61)\end{array}$ & $\begin{array}{l}1.74 \\
(0.43)\end{array}$ \\
\hline$\Delta \mathbf{I}$ & $\begin{array}{l}-1.05 \\
(2.80)\end{array}$ & $\begin{array}{c}4.93 \\
(1.43)\end{array}$ & $\begin{array}{c}9.14 \\
(2.59)\end{array}$ & $\begin{array}{c}2.58 \\
(0.94)\end{array}$ & $\begin{array}{c}2.04 \\
(1.56)\end{array}$ & $\begin{array}{c}1.35 \\
(1.08)\end{array}$ \\
\hline$\Delta c$ & $\begin{array}{c}1.75 \\
(0.53)\end{array}$ & $\begin{array}{c}2.98 \\
(0.60)\end{array}$ & $\begin{array}{c}2.71 \\
(0.61)\end{array}$ & $\begin{array}{c}2.36 \\
(0.28)\end{array}$ & $\begin{array}{c}2.70 \\
(0.34)\end{array}$ & $\begin{array}{c}2.34 \\
(0.32)\end{array}$ \\
\hline $1(G-7)$ & $\begin{array}{c}3.81 \\
(0.65)\end{array}$ & $\begin{array}{c}3.26 \\
(0.73)\end{array}$ & $\begin{array}{c}4.80 \\
(1.14)\end{array}$ & $\begin{array}{c}2.95 \\
(0.46)\end{array}$ & $\begin{array}{c}3.58 \\
(0.77)\end{array}$ & $\begin{array}{c}3.93 \\
(0.57)\end{array}$ \\
\hline$=(G-7)$ & $\begin{array}{l}-0.65 \\
(0.78)\end{array}$ & $\begin{array}{l}-0.28 \\
(0.90)\end{array}$ & $\begin{array}{l}-0.05 \\
(0.52)\end{array}$ & $\begin{array}{l}-0.84 \\
(0.34)\end{array}$ & $\begin{array}{l}-0.65 \\
(0.48)\end{array}$ & $\begin{array}{c}0.66 \\
(0.34)\end{array}$ \\
\hline unc & $\begin{array}{l}-3.15 \\
(2.57)\end{array}$ & $\begin{array}{l}-3.60 \\
(1.97)\end{array}$ & $\begin{array}{c}0.77 \\
(2.00)\end{array}$ & $\begin{array}{l}-0.77 \\
(1.03)\end{array}$ & $\begin{array}{l}-0.65 \\
(1.29)\end{array}$ & $\begin{array}{c}0.34 \\
(1.03)\end{array}$ \\
\hline EXCE RATE & $\begin{array}{l}-4.15 \\
(1.46)\end{array}$ & $\begin{array}{l}-3.78 \\
(1.68)\end{array}$ & $\begin{array}{l}-2.30 \\
(1.98)\end{array}$ & $\begin{array}{l}-2.26 \\
(0.72)\end{array}$ & $\begin{array}{l}-2.12 \\
(1.06)\end{array}$ & $\begin{array}{l}-1.82 \\
(0.76)\end{array}$ \\
\hline Trado balance & $\begin{array}{c}0.33 \\
(0.86)\end{array}$ & $\begin{array}{c}1.72 \\
(0.52)\end{array}$ & $\begin{array}{c}0.13 \\
(0.37)\end{array}$ & $\begin{array}{c}0.46 \\
(0.22)\end{array}$ & $\begin{array}{c}0.21 \\
(0.25)\end{array}$ & $\begin{array}{c}0.21 \\
(0.27)\end{array}$ \\
\hline VALULC & $\begin{array}{c}0.87 \\
(0.45)\end{array}$ & $\begin{array}{c}2.63 \\
(0.69)\end{array}$ & $\begin{array}{l}-0.27 \\
(0.63)\end{array}$ & $\begin{array}{c}0.10 \\
(0.27)\end{array}$ & $\begin{array}{c}0.53 \\
(0.36)\end{array}$ & $\begin{array}{l}-0.08 \\
(0.28)\end{array}$ \\
\hline WSB & $\begin{array}{l}57.30 \\
(1.26)\end{array}$ & $\begin{array}{l}54.91 \\
(1.23)\end{array}$ & $\begin{array}{l}54.32 \\
(1.40)\end{array}$ & $\begin{array}{l}52.46 \\
(0.76)\end{array}$ & $\begin{array}{l}51.97 \\
(1.08)\end{array}$ & $\begin{array}{l}52.39 \\
(0.77)\end{array}$ \\
\hline PSE & $\begin{array}{l}28.08 \\
(1.39)\end{array}$ & $\begin{array}{l}30.28 \\
(1.25)\end{array}$ & $\begin{array}{l}30.01 \\
(1.16)\end{array}$ & $\begin{array}{l}32.42 \\
(0.58)\end{array}$ & $\begin{array}{l}32.35 \\
(0.84)\end{array}$ & $\begin{array}{l}32.85 \\
(0.63)\end{array}$ \\
\hline
\end{tabular}

Source: OECD.

1f "Before" is the two-year period before the adjustment. "During" is the adjustment perlod. "After" 13 the two-year period after the adjustment. GR (G-7) is the yearly average growth of GDP relative to the G-7 average, waighted by GDP. U (G-7) lo the unemployment rate relative to G-7 average. $\Delta I$ is the yearly rate of growth of private investment. $\Delta C$ is the average yearly rate of growth of consumption. 1 (G-7) 1 s a nominal long-terw Interest rate (10-year govermment bond) relative to G-7 averege. I (G-7) 1s the real long Interest rate computed as [ $L(G-7)-1$ felation, relative to G-7]. ULC is the yearly rate of change of relative unit labor costs. EXCB RATE 1a the rate of change of the nominal effective exchenge rate. VAULC 13 the rate of change of the value added deflator over untt labor costs; WSH 15 the rage share over GDP and PSB is the profit share over GDP. See Appendlx for a more precise definttion of all of these variables. Standard deviatione in parentheses. 
This table suggests that perhaps the strongest channel influencing the macroeconomic consequences of fiscal adjustment goes through unit labor costs, via their effects on investment and exports; this channel may be at least as important, if not more, than the channels typically emphasized in the literature, based upon "wealth effects cum expectations" on consumption and credibility effects on consumption. The discussion which follows in the next section concerning three case studies sheds some more light on this issue.

Needless to say, Table 10 is far from conclusive and much more statistical evidence is necessary to disentangle various channels through which fiscal adjustments can influence the economy. In particular, several critical issues need to receive more attention:

(i) More work is needed to disentangle the effects of exchange rate depreciations and wage moderation on the likelihood of success of fiscal adjustments. One interpretation of the evidence presented above is that the composition of successful adjustments induces wage moderation, while the composition of unsuccessful ones does not. A critical exhibit in favor of this interpretation is the fact that during successful adjustments government wages are cut and government employment does not increase much, while at the same time taxes on household are constant. According to the models and the empirical

evidence presented by Alesina and Perotti (1994 and 1995b) and Perotti and Lane (1996), these features should imply wage moderation on the part of the unions. On the contrary, the features of unsuccessful adjustments, namely higher increase in taxes and no cuts on government wages and employment have the opposite effects on unit labor costs. However, several major multi year fiscal adjustments (see next section) are preceded by a devaluation of the exchange rate. Disentangling the effects of wage moderation and the effects of fiscal variables on the supply side and the cost of firms, versus the effect of the exchange rate is a critical next step to understand the dynamics of fiscal adjustments.

(ii) Table 10 shows that growth is significantly higher during successful adjustments than during unsuccessful ones. Our favorite interpretation is that the composition of the adjustment through its credibility, wealth, and, especially, unit labor cost effects influences growth. An alternative interpretation is that successful adjustments are such because growth is, for some exogenous reason, particularly high during these episodes. While our evidence cannot be conclusive on this point, the alternative interpretation which argues that growth explains success, fails to provide an explanation of the difference in composition between successful and unsuccessful adjustments. If everything is driven by exogenous growth effects, than successful and unsuccessful adjustments should look approximately the same in terms of their composition. 


\section{Sensitivity and comparisons with previous results}

Sensitivity analysis on our results shows that they are robust to changes in the definitions. For instance, we have relaxed the definition of success as follows:

Definition 3: A period of tight fiscal policy is successful if either one of the following two conditions applies: (i) the average cyclically adjusted primary deficit as a share of GDP is on average lower than in the last year of the tight policy, and (ii) the debt to GDP ratio three years after the last year of the adjustment is below the level of the last year of the adjustment.

With this new definition we now have 38 observation/years of success, corresponding to 28 episodes, and 24 observation years of failures. Table 11 considers the difference in the composition of expenditure cuts and tax increases and should be compared with table 4 above. The differences between successful adjustments and unsuccessful ones are very similar to those of Table 4, in fact they are slightly larger. Interestingly, the size of the adjustment is virtually identical.

Table 12 considers the composition of spending cuts, and should be compared with Table 6 . The difference in composition remains striking. Virtually all the adjustment in unsuccessful cases ( 84 percent of total spending cuts) is on public investment, while transfers and government wages slightly increase. In successful cases cuts of transfers and government wages are about half of the total expenditure reductions. The difference in the composition of tax increases are qualitatively similar to those reported above in Tables 8 and 9 .

As for the macroeconomic consequences, using this alternative definition of success we obtain results which are quite similar to those reported in Table 10, although as should be expected, the difference between success and failures are a bit smaller. The behavior of unit labor costs remain the most striking difference between the two types of adjustments.

We also have relaxed our definition of what a "tight" policy is, reducing (in absolute value) the threshold level for a definition of tight policy. For instance, we have considered as "tight" episode any two-year period where BFI is lower than -1 , as opposed to -1.25 as in our definition 1 . Our results do not change qualitatively. Further experiments combining different definitions of "tight episodes" and "success" confirm the general robustness of our results. 1

1) All these results are available upon request. 
Also, a comparison with our previous results presented in Alesina and Perotti (1995a) and (1996) confirms that the basic picture painted in this section is quite robust. In our previous papers we have used a definition of tight policy which included only one year adjustments. What we have done here improves upon this definition by including two-year period of "moderate adjustment" each year rather than only one year of sharp adjustment. We have also improved upon our previous definition of success by focusing on the flow of deficits rather than only on the stock of debt as a criterium of success. Finally, in this paper we use an updated data set and we use only observations with a full set of usable observations. Also we consider many more macroeconomic variables and we make some progress toward disentangling the macroeconomic effects of adjustments, particularly those related to the external sector and exchange rate movements.

McDermott and Wescott (1996) use a similar methodology to ours. Their definitions are a combination of what we use in this paper and we used in our previous work. Their definition of tight fiscal policy allows for two or three year periods of consecutive tightening. Their definition of success is based only on the improvement in the debt to GNP ratio. They also use a different methodology for the cyclical adjustment. As far as the composition is concerned they confirm our result on the spending side. This is quite reassuring, given the several difference in their definitions and procedures. They also have similar findings concerning the size of the adjustment in successful and unsuccessful cases. They interpret this finding as saying that the size of the adjustment is very important. We still find the differences in the composition more impressive than the difference in size, particularly in light of the results of Table 11.

Table 11. Successful and Unsuccessful Adjustment, Alternative Definition, Expenditures and Revenues $1 /$

\begin{tabular}{lcccc}
\hline \multicolumn{1}{c}{$\begin{array}{c}\text { Number of } \\
\text { Observations }\end{array}$} & $\begin{array}{c}\text { Fiscal } \\
\text { Impulse }\end{array}$ & $\begin{array}{c}\text { Primary } \\
\text { Expenditures }\end{array}$ & Revenues \\
\hline Successful adjustments & 38 & -2.61 & -1.66 & 0.96 \\
& & $(0.17)$ & $(0.21)$ & $(0.19$ \\
Unsuccessful adjustments 24 & -2.50 & -0.84 & 1.64 \\
& & $(0.43)$ & $(0.46)$ & $(0.24$ \\
\hline
\end{tabular}

Source: $O E C D$.

1/ All variables are in changes of ratios over GDP. Standard deviations in parentheses. 
Table 12. Successful and Unsuccessful Adjustments, Alternativa Definition.

Expenditure Cuts as a Share of Total Expenditure Cuts

\begin{tabular}{|c|c|c|c|c|c|c|c|}
\hline & $\begin{array}{c}\text { Number of } \\
\text { Observations }\end{array}$ & $\begin{array}{c}\text { Publle } \\
\text { Inves tment } \\
\text { (1) }\end{array}$ & $\begin{array}{c}\text { Transfers } \\
\text { (2) }\end{array}$ & $\begin{array}{c}\text { Government } \\
\text { Wages } \\
\text { (3) }\end{array}$ & $\begin{array}{l}\text { Columans } \\
(2)+(3)\end{array}$ & $\begin{array}{c}\text { Nonwage Gove. } \\
\text { Consumption } \\
\text { (4) }\end{array}$ & $\begin{array}{c}\text { Subsidies } \\
\text { (5) }\end{array}$ \\
\hline $\begin{array}{l}\text { Successful } \\
\text { adjustoments }\end{array}$ & 38 & $\begin{array}{l}-0.33 \\
(0.09)\end{array}$ & $\begin{array}{l}-0.24 \\
(0.06)\end{array}$ & $\begin{array}{l}-0.19 \\
(0.04)\end{array}$ & -0.43 & $\begin{array}{l}-0.10 \\
(0.02)\end{array}$ & $\begin{array}{l}-0.09 \\
(0.05\end{array}$ \\
\hline $\begin{array}{l}\text { Unsuccassful } \\
\text { adjustments }\end{array}$ & 24 & $\begin{array}{l}-0.84 \\
(0.64)\end{array}$ & $\begin{array}{c}0.03 \\
(0.12)\end{array}$ & $\begin{array}{c}0.04 \\
(0.11)\end{array}$ & 0.07 & $\begin{array}{l}-0.08 \\
(0.06)\end{array}$ & $\begin{array}{l}-0.11 \\
(0.10\end{array}$ \\
\hline
\end{tabular}

Source: OECD. Standard deviations in parentheses.

Using a rather different methodology, based upon estimating consumption functions, Giavazzi and Pagano (1996) argue that large and persistent fiscal adjustments are expansionary, while smaller ones are not because of credibility and wealth effects.

Bartolini, Razin, and Symansky (1995) use the MULTIMOD model to study the effects of fiscal adjustments in the G-7 countries. They find that adjustments have short-run output cost and long run benefits. However, adjustments relying on increases in indirect taxes and expenditures have a quicker recovery relative to other types of adjustments, a result which is quite consistent with our evidence presented above.

\section{v. Three Major Fiscal Adjustments}

In the previous sections we have argued that one can identify two types of fiscal adjustments. Type 1 adjustments rely primarily on spending cuts; the components of spending which receive the largest cuts are transfer programs and government employment and wages. Furthermore, in these adjustments taxes on households are kept constant, or even reduced. Type 2 adjustments rely primarily on tax increases, particularly on households and spending cuts in public investment. We have shown that Type 1 adjustments are more permanent and expansionary, while Type 2 tend to be reversed by further deteriorations of the budget and have worse macroeconomic consequences.

In this section we argue that the Irish adjustment in the late eighties (1986 to 1989) is of Type 1 ; instead, the Danish adjustment of 1983-86 has substantially different feacures from the Irish one and lies somewhere in between Type 1 and Type 2. Finally, we suggest that the current Italian adjustment is of Type 2, at least up until 1995. 


\section{The Irish adjustment 1987-89}

Ireland entered the 1980 s with a serious fiscal problem: the borrowing requirement was nearly 16 percent of GNP. In 1982-84 a weak and divided coalition government engaged in a fiscal adjustment almost completely on the revenue side. In particular, taxes on households were sharply raised. The only modest spending cuts were on public investment. This looks like a "textbook case" of "Type 2" adjustment. The Irish pound was pegged to EMS currency leading to a rapid disinflation with falls in interest rates, however the stabilization failed to permanently consolidate the budget and had very strong negative effects on domestic demand. The fiscal balance continued to deteriorate in 1984-86, mostly due to increases in the interest burden and of primary spending; the latter grew by about 2 percentage points of GDP in these three years.

In 1987, the gross debt/GDP ratio peaked at almost 120 percent. A new government elected in February of that year launched an adjustment program with totally different features from the failed one of the early eighties. This adjustment lead to a sharp drop in the debt to GDP ratio in the following five years (from almost 120 percent to slightly more than 90 percent) and to rates of growth well above OECD or $6-7$ averages. The turnaround of the Irish economy started in 1987 is remarkable.

\section{a. Size and composition of the adjustment}

Table 13 summarizes several features of the Irish adjustment. Our measure of cyclically adjusted primary surplus (BFI) improves by about 8 percent of GDP from 1985-86 to 1990-90. The entire adjustment is on the spending side. The only moderate increase in household taxes during the adjustment is entirely due to a one off tax amnesty in 1988. Total revenues (including taxes on households) as a share of GDP were lower in 1989-90 than in 1986.

The spending cuts were broad ranging but the largest in terms of share of GDP were on transfers, which fell by more than 2.5 percent of GDP. The government wage bill and public investment received the second largest reduction. Reductions in government wages were obtained by an agreement in 1987 with the unions to limit pay increase to 2.5 percent, well below inflation. More important was the large reduction in public employment. Between 1986 and 1989 total public employment was cut by about 10 percent, from 300,000 to 270,000 . This development was the result of an hiring freeze instituted in 1987, early retirement schemes, and voluntary redundancy schemes. $1 /$ Social spending cuts were mostly in the health sector.

1) In order to facilitate voluntary resignations, the Government sponsored retraining programs designed to help individuals leave the public sector. These relatively cheap prograns were quite successful. 
Table 13. Ireland: Fiscal Adjustment Size and Composition, 1987-89 I/

\begin{tabular}{|c|c|c|c|c|c|}
\hline & $\begin{array}{r}\text { Before } \\
\text { (1) }\end{array}$ & $\begin{array}{l}\text { During } \\
\text { (2) }\end{array}$ & $\begin{array}{r}\text { After } \\
(3)\end{array}$ & $\begin{array}{r}\text { Diff. } \\
(2)-(1)\end{array}$ & $\begin{array}{r}\text { Diff. } \\
(3)-(1)\end{array}$ \\
\hline Fiscal impulse & -3.5 & 2.1 & 4.4 & 5.6 & 7.9 \\
\hline Primary expenditures & 40.6 & 35.3 & 33.8 & -5.3 & -6.8 \\
\hline Transfers & 17.4 & 16.0 & 14.8 & -1.4 & -2.6 \\
\hline Government wages & 12.2 & 11.0 & 10.7 & -1.2 & -1.5 \\
\hline Nonwage public consumption & 7.4 & 6.2 & 6.3 & -1.1 & -1.0 \\
\hline Public investment & 3.6 & 2.1 & 2.1 & -1.5 & -1.5 \\
\hline Revenues & 35.9 & 35.9 & 34.5 & 0.0 & -1.4 \\
\hline Taxes on households & 12.9 & 13.4 & 12.2 & 0.5 & -0.7 \\
\hline Taxes on business & 1.3 & 1.3 & 2.0 & 0.0 & 0.7 \\
\hline Indirect taxes & 16.3 & 16.0 & 15.0 & -0.3 & -1.3 \\
\hline $\begin{array}{l}\text { Social security } \\
\text { contributions }\end{array}$ & 5.4 & 5.2 & 5.3 & -0.2 & -0.1 \\
\hline
\end{tabular}

Source: OECD.

1) "Before" is the two-year period before the adjustment, thus 1985-86; "during" is the period of the adjustment, 1987-89; "after" is the two-year period after the adjustment, thus 1990-91. All variables are in shares of GDP.

\section{b. Tax reform and wage bargaining}

In 1988 a broad tax reform was introduced and took effect in 1989. A cornerstone of it was a cut in marginal tax rates on the income of households. The top rate which was as high as 65 percent in 1984-85 was reduced to 56 percent, but also the standard rate was cut from 35 percent to 32 percent. These cuts were accompanied by an increase in standard allowances. The Irish tax system is quite progressive, therefore these tax cuts reached very low in the income ladder. The corporate income tax was also reduced from 47 to 43 percent. 
Wage bargaining had a decentralized nature throughout the eighties. On the contrary, a centralized wage agreement was reached in 1987 in the context of the Program For National Recovery (PNR). The accord covering 1988-90 insured wage moderation both in the private and in the public sector. A very large majority of firm level wage agreenents were in line with the guidelines established by the accord between the government and the national union. We claim that this tax reform and the wage bargaining agreements are not unrelated. As argued in the previous section, wage moderation was achieved probably because the unions internalized the increase in the after tax disposable income due to the tax cuts, in addition to the effects of a soft labor market with high unemployment. Also the more or less voluntary layoffs in the public sector probably contributed to increase union' moderation at the bargaining table.

\section{c. Macroeconomic consequences of the adjustment}

The year 1987 marks a remarkably positive turnaround for the Irish economy. Unemployment started to decrease in 1988 after a rising trend which had lasted 25 years. Table 14 shows that growth which was almost 2 percent below G-7 average before the adjustment was well above G-7 average during and after the adjustment. GDP growth was sustained by both domestic and foreign factors. Domestic consumption grew at steady rates during and after the adjustment, mostly due to consumer durables, particularly automobiles. Private investment increased and picked up the slack left by the contracting public investment. The external sector was sustained by the devaluation of the Irish pound of 1987 and by the policy of wage moderation obtained in the same year.

Nominal and real rates fell dramatically between 1987 and 1989 both in absolute terms and relative to Germany. Short-term real rates (defined as nominal minus actual inflation) fell from about 11 percent at the end of 1986 to about 7 percent in 1989. Differential of these rates with Germany fell from about 7 in 1986 to about 3 in 1989. Similar developments occurred on long rates, with a differential of real rates respect to Germany falling from about 5 in 1986 to about 2 in 1989. These developments are an indication of credibility effects in asset markets, as pointed out by Dornbusch (1989).

The increase in market value of private wealth due to the fall in interest rates generated a positive wealth effect in consumption. As noted by Giavazzi and Pagano (1990) an effect on liquidity constrained individuals, who obtained an increase in disposable income due to the tax cuts, was a second source of the increase in private consumption. Interestingly, most of the increase in consumption came from durables, perhaps implying a strong interest rate effect.

All indicators of competitiveness show marked improvements between 1986 and 1989. For instance, IMF staff calculations of relative unit labor costs fell by a cumulative 15 percent in this period. Our measure of relative unit labor costs fell by about 10 percent in the same period. These develop- 
ments are the result of the combined effect of wage moderation and the devaluation of the Irish pound. The trade balance improved during the adjustment despite the booming domestic demand (Table 14).

The effect of wage moderation is apparent in the evolution of distributional shares (see Table 14). The wage share fell from about 54 percent before the adjustment to about 50 afterward, while the profit share gained about five points in the same period. IMF Staff calculation of profitability also show a sharp improvement in ten same period. For instance the ratio of wholesale prices over unit labor costs increased by more than 20 percent between 1986 and 1989 . The ratio of export unit value over unit labor costs displays a similar pattern.

Table 14. Ireland: Macroeconomic Conditions and the Fiscal Adjustment, 1987-89

\begin{tabular}{lccccc}
\hline & $\begin{array}{c}(1) \\
\text { Before }\end{array}$ & $\begin{array}{c}(2) \\
\text { During }\end{array}$ & $\begin{array}{c}(3) \\
\text { After Diff }(2)-(1) \text { Diff (3) - (1) }\end{array}$ \\
\hline GR (G-7) & -1.72 & 1.89 & 3.86 & 3.61 & 5.58 \\
U (G-7) & 9.80 & 10.80 & 8.63 & 1.00 & -1.17 \\
$\Delta \mathrm{I}$ & -7.71 & 8.31 & 1.31 & 16.02 & 9.02 \\
$\Delta \mathrm{C}$ & 2.47 & 5.78 & 1.93 & 3.31 & -0.54 \\
i (G-7) & 3.41 & 2.14 & 1.43 & -1.27 & -1.98 \\
ULC & 8.67 & -2.73 & 2.16 & & - \\
EXCH RATE & 3.30 & -1.03 & 3.31 & & -3.82 \\
TB & 1.51 & 2.27 & -1.91 & & 4.73 \\
WSH & 54.23 & 51.58 & 50.41 & -2.65 & \\
PSH & 21.75 & 25.32 & 26.48 & 3.57 & \\
\hline
\end{tabular}

Source: OECD. For a definition of the variables see Table 10 .

\section{The Danish adjustment 1983-86}

The fiscal position of Denmark deteriorated rapidly starting in the late 1970s, reaching the highest deficits in 1982: in that year the central government deficit was more than 11 percent of GDP. The worsening of the 
fiscal balance was entirely due to a sharp increase in expenditures, from about 44 percent of GDP in 1978 to almost 54 percent in 1982 . The gross debt/GDP ratio reached almost 80 percent in 1982, and a large fraction of it (by OECD standard) was foreign debt. 1/ Average bond yield peaked at about 20 percent in 1982, when inflation was about 9 percent. The real rate differential between Denmark and Germany was about 8 percent in 1982 . In October 1982 S\&P added a credit watch to the AAA rating of Danish government bonds.

In October 1982 a convincing electoral victory established a cohesive conservative coalition into office. This government launched a major fiscal adjustment program which took place in the following four years. At the same time the govermment announced that the exchange rate was irrevocably fixed and the series of devaluations in the previous years had ended. As pointed out by Giavazzi and Pagano (1990), the credibility of this announcement was cemented by the lack of a Danish devaluation in March 1983, at the time of a general EMS realignment.

\section{a. Composition of the adjustment}

Table 15 shows that the turnaround of Danish fiscal position was remarkable: the largest in the recent history of any OECD economy. By $1987 / 88$ our cyclically adjusted measure of budget deficit improved by more than 11 percent of GDP relative to 1981/82. The adjustment was about equally divided between expenditure cuts and tax increases.

On the expenditure side most of the cuts were on transfer prograns and government wages (see Table 15). Cuts in transfer programs were broad ranging and focused on unemployment insurance (freezing of maximum rate and reduction of abuses), changes in the parameter of pensions schemes, particularly on public employees, cuts in sickness insurance funds. Transfer to local governments were also reduced in 1983-85. As shown in Table 15 transfers fell by more than 1 percent of GDP during the adjustment. Public employment which had been growing rapidly before 1982, was frozen. In the context of the income policies introduced in 1982, government sector wages grew less than inflation. Wage indexation was suspended until 1987, and the automatic link of public sector wages to wage increases in the private sector was eliminated. The result of all these measures was a substantial reduction in the government wage bill.

On the revenues side, most of the increase in revenues was due to direct taxes on household and business, with more modest increases in indirect taxes (Table 15). In the context of the policy of cuts in net transfers, several social security contribution were increased, including contribution from employees to the unemployment fund and tax subsidies to private pension schemes. The result was a substantial increase in the tax burden for families in the period 1982-87.

1) External debt was about 35 percent of GDP. 


\section{b. Macroeconomic consequences of the fiscal adjustment}

The average growth rate during the adjustment in 1983-86 was about 3.3 percent per year, well above the G-7 average (Table 16). Both consumption and especially private investment boomed. The latter grew by more than 10 percent per year and the former by more than 3 percent. The share of private investment grew by almost 2.5 points of GDP relative to 1981/82. Export increased steadily as a result of improvements of competitiveness (reduction of relative unit labor costs), due in part to the depreciation of the exchange rate in the early 1980 s and to the wage moderation accord of 1982, coupled with a suspension of indexation clauses. The effect of this wage policy is reflected in Table 16 in a sharp drop of the wage share and an even larger increase in the profit share in the period 1983-86 relative to the previous two years.

Giavazzi and Pagano (1990) emphasize the expansionary consequences of the "credibility effect" and of the "wealth effect" in these four years. Interest rates dramatically fell immediately after the fiscal adjustment was announced and the implementation started. Giavazzi and Pagano (1990) calculate that their measure of an ex ante real rate fell from 6.7 in the 1979-82 period to 3.3 for the $1983-86$ period of fiscal adjustment. Differential with real German rates were at least halved, dropping from about 8 percent to less than 4 percent. Table 16 also shows a sharp drop of ex post real rates relative to $G-7$, from almost 5 before the adjustment to less than 2 during, to less than 1.5 after. Another indicator of the credibility of the adjustment was a jump upward of indicators of consumer confidence.

The sharp drop in real interest rates, accompanied by the wage moderation achieved in 1982, the increase in the profit share and the reduction in unit labor costs all contributed to the boom in private investment.

\section{c. Immediate aftermath}

Giavazzi and Pagano (1990) interpret the Irish and the Danish adjustments as two cases of expansionary fiscal consolidations, and emphasize their similarities. However, the immediate aftermath of the two adjustments show that they were quite different. While the Irish economy continued booming after the adjustment, the Danish economy turned into a recession in 1987 and 1988 with growth rates of -.6 and -.2 , respectively: average growth in Denmark was more than 3 percent lower than in the G-7 in both 1987 and 1988 (Table 16). In 1989 growth was only 1.1 percent. Unemployment increased in 1988 from 7.9 to 8.7 an continued to climb in the following two years. The Irish and Danish adjustments look quite different. 
Table 15. Denmark: Adjustment Size and Composition, 1983-86 $1 /$

\begin{tabular}{lrrrrr}
\hline & $\begin{array}{r}\text { Before } \\
(1)\end{array}$ & $\begin{array}{r}\text { During } \\
(2)\end{array}$ & $\begin{array}{r}\text { After } \\
(3)\end{array}$ & $\begin{array}{r}\text { Diff. } \\
(2)-(1)\end{array}$ & $\begin{array}{r}\text { Diff. } \\
(3)-(1)\end{array}$ \\
\hline Fiscal impulse & -5.7 & 2.7 & 5.7 & 8.4 & 11.4 \\
Primary expenditures & 50.4 & 46.4 & 46.6 & -4.0 & -3.8 \\
Transfers & 19.7 & 18.6 & 19.0 & -1.1 & -0.7 \\
Government wages & 19.9 & 18.3 & 18.2 & -1.6 & -1.7 \\
Nonwage public consumption & 8.0 & 7.3 & 7.2 & -0.7 & -0.8 \\
Public investment & 2.8 & 2.2 & 2.2 & -0.6 & -0.6 \\
Revenues & 45.7 & 49.3 & 50.4 & 3.6 & 4.7 \\
Taxes on households & 24.4 & 25.6 & 28.1 & 1.2 & 3.7 \\
Taxes on business & 1.1 & 2.4 & 2.3 & 1.3 & 1.2 \\
Indirect taxes & 18.0 & 18.5 & 19.2 & 0.5 & 1.2 \\
Social security & & & & & 0.6 \\
contributions & 2.2 & 2.8 & 2.8 & 0.6 & \\
\hline
\end{tabular}

Source: OECD.

1 "Before" is the two-year period before the adjustment, thus 1981-82; "during" is the period of the adjustment, 1983-86; "after" is the two-year period after the adjustment, thus 1987-89. All variables are in shares of GDP. 
Table 16. Denmark: Macroeconomic Conditions and the Fiscal Adjustment, 1983-86

\begin{tabular}{lccccc}
\hline & $\begin{array}{c}\text { Before } \\
(1)\end{array}$ & $\begin{array}{c}\text { During } \\
(2)\end{array}$ & $\begin{array}{c}\text { After } \\
(3)\end{array}$ & $\begin{array}{c}\text { Diff } \\
(2)-(1)\end{array}$ & $\begin{array}{c}\text { Diff } \\
(3)-(1)\end{array}$ \\
\hline GR (G-7) & 0.40 & 0.38 & -3.06 & -0.2 & -3.46 \\
U (G-7) & 2.21 & 1.55 & 1.36 & -0.66 & -0.85 \\
$\Delta$ I & 1.69 & 13.42 & -6.36 & 11.73 & -8.05 \\
$\Delta C$ & -0.44 & 4.17 & -1.26 & 4.61 & -0.82 \\
I (G-7) & 8.55 & 3.36 & 2.43 & -5.19 & -6.12 \\
I (G-7) & 4.94 & 1.99 & 1.46 & -2.95 & -3.48 \\
ULC & -13.85 & 0.29 & 8.25 & & \\
EXCH RATE & -4.53 & 1.16 & 0.92 & & 1.47 \\
TB & 0.80 & 0.03 & 1.50 & -0.77 & -0.64 \\
WSH & 56.20 & 54.17 & 55.56 & -2.03 & 1.52 \\
PSH & 31.57 & 35.14 & 33.09 & 3.57 & \\
\hline
\end{tabular}

Source: OECD. For a definition of the variables see Table 10.

The underlying cause of the Danish recession lies in the fall in competitiveness. The real effective exchange rate (relative unit labor costs) as measured by the IMF fell by 8 percent in 1986 and almost 11 percent in 1987. The current account deficit increased to almost 6 percent of GDP in 1986. The trade balance worsened during the adjustment, as shown in Table 16, particularly in 1985-86. The improvenent of the trade balance after the adjustment is largely driven by the recession.

The decrease in competitiveness can only be partially explained by the appreciation of the real exchange rate due to the rapidly falling inflation with a fixed nominal rate. An important additional factor was the wage agreement of early 1987, which introduced sizeable wage increases for 1987 and 1988. Their effects, after the restraint during the period 1982-86, is shown in Table 16 by a rebound of the wage share which increased by more than 1 point of GDP relative to the average of 1983-86. The profit share, on the contrary fell of about 2 percentage points. 
Our interpretation is that the wage accord of 1987 incorporated union demands for compensations for the increase in income taxes of the previous four years, which reduced workers' after tax income. Thus, the tax increases might have been the originating cause of the recession, via wage negotiations, as implied by Alesina and Perotti (1994).

\section{The Italian adjustment from 1989}

The beginning of a fiscal adjustment in Italy can de dated back to 1989. However, despite the reduction in the primary deficit which turned into a surplus in 1991, the debt to GNP ratio continued to increase reaching 125 percent in 1994. Only in 1995 this ratio declined slightly. Until 1993 the adjustment was completely on the revenue side. In Eact the ratio of primary spending over GNP increased between 1989 and 1993. Thus, the adjustment between 1989 and 1993 looks clearly of "Type 2." From 1993 to 1995 primary spending was cut and revenues fell. Thus, at first sight, one may be tempted to conclude that from 1993 onward, the Italian adjustment is of Type 1. However, a more careful examination of the evidence suggests that this interpretation is questionable.

\section{a. Size and composition of the adjustment}

Table 17 considers the general government, the definition which is the most compatible with the one used for the other countries in this study. 1/ First of all, the overall size of the adjustment, from 1994-95 relative to 1989 is much smaller than the one of Denmark and Ireland, despite being stretched over a longer period. In terms of share of GDP the adjustment in the primary surplus is about half of the Irish adjustment and not more than one third of the Danish adjustment, despite the fact that Italy had a much higher debt to GDP ratio of Denmark and a much higher interest burden. Until 1993 the adjustment was totally on the revenue side, with revenues increasing of 6.3 per cent of GDP and reaching 48.3 percent. Primary expenditures rose of 3.7 percent of GDP. Total expenditures reached 57.8 percent in 1993. After the spending and tax cuts of 1994 and 1995. primary expenditures returned to their 1989 level as a share of GDP, and revenues are still 3.5 percent of GDP above the 1989 level. The reduction in revenues in the last two years is largely due to the fact that many of the tax increases in 1992-93 had a "one off" nature.

1) Fiscal data for Italy are drawn from IMF, specifically from the latest RED and its appendices (March 1996). Since data for 1995 are particularly important for the Italian adjustment, we could not use our OECD daca set, which we adopted above, since that data ends at 1994. Also, for the case of Italy, it is particularly useful to contrast the central government data with the general government data. 
Table 17. Italy: Fiscal Adjustment General Government, 1989-95

\begin{tabular}{|c|c|c|c|c|c|c|}
\hline & 1989 & 1993 & $1994-95$ & $\frac{\text { Diff. }}{1993 / 89}$ & $\frac{\text { Diff. }}{1994-95 / 89}$ & $\frac{\text { Diff. }}{1994-95 / 93}$ \\
\hline Revenues & 42.0 & 48.3 & 45.5 & 6.3 & 3.5 & -2.8 \\
\hline Expenditures & 51.9 & 57.8 & 53.5 & 5.9 & 1.6 & -4.3 \\
\hline Interest payments & 8.9 & 12.1 & 10.8 & 3.2 & 1.9 & -1.3 \\
\hline $\begin{array}{l}\text { Primary } \\
\text { expenditures }\end{array}$ & 43.0 & 45.7 & 42.7 & 3.7 & -0.3 & -3.0 \\
\hline Wages & 11.9 & 12.5 & 11.7 & 0.6 & -0.2 & -0.8 \\
\hline Social security & 17.6 & 19.5 & 19.1 & 1.9 & 1.5 & -0.4 \\
\hline Subsidies & 2.5 & 2.3 & 2.1 & -0.2 & -0.4 & -0.2 \\
\hline $\begin{array}{l}\text { Other current } \\
\text { expenditures }\end{array}$ & 1.3 & 1.4 & 1.1 & 0.1 & -0.2 & -0.3 \\
\hline Fixed investment & 3.3 & 2.7 & 2.2 & -0.6 & -1.1 & -0.5 \\
\hline $\begin{array}{l}\text { Other capital } \\
\text { expenditures }\end{array}$ & 1.5 & 2.1 & 1.5 & 0.6 & 0.0 & -0.6 \\
\hline Overall balance & -9.9 & -9.6 & -8.1 & 0.3 & 1.8 & 1.5 \\
\hline Primary balance & -1.0 & 2.6 & 2.8 & 3.6 & 3.8 & 0.2 \\
\hline
\end{tabular}

Source: IMF. 
The composition of the spending cuts in 1994-95 is quite revealing. The largest share of the cut comes from capital expenditures ( 1.1 percent of GDP). The remaining cuts between 1993 and $1994-95$ are mostly from government wages (almost 1 percent of GDP) and other modest cuts on all the other items. However, despite these recent cuts, in 1995 government wages have about the same share of GDP, as in 1989, and social security increased by 1.5 percent of GDP, relative to that same year.

The fall in public investment is partly (or largely) due to the effects of criminal investigations known as "mani pulite" (clean hands) and it is unlikely that these cuts will be sustainable. Certainly a good portion of this reduction has a "one shot" nature. A sizable part ( 0.6 percent of GDP) of the total cuts on the capital spending account falls in the category of "other capital spending." This entry includes refunds of tax credits of the public. In 1993 this entry was unusually high (2.1 of GDP). In 1995 although almost 1 percent of GDP of tax refunds were planned (Lit 16,000 billion) only Lit 700 billion was disbursed. On average about Lit 5,000 billion is disbursed every year. Thus, the postponement of tax refund in 1995 is largely responsible for a large part of the so-called cut in capital spending.

The reduction of the wage bill results form a hiring freeze, but especially from a less than full adjustment of public wages to inflation. An agreement with the unions in 1992 linked wages to planned rather than actual inflation. Since in the following three years actual inflation has been above planned, real wages have fallen. Currently the unions ar asking for an adjustment to wages to compensate for this difference. Whether this adjustment will occur in full in the next few years is unclear. The point is that the real wage reduction is the result of a rather convoluted and (perhaps) strategic use of projected and actual inflation rather than a clear and permanent agreement with the unions for a wage restraint. I/

Social security received some cuts in 1995 relative to 1994. As pointed out by the Bank of Italy (1996) these savings have a temporary nature and are due mostly to two "one off" measures: (i) some temporary suspensions of "liquidazioni" (severance pay) of public employees and some other postponement of payments of certain pensions, (ii) postponement from November of 1995 to January of 1996 of indexation payments.

While the concept of general government is the most relevant for international comparisons (and for the EMU criteria) the budget documents in Italy, the authorities' goals and most of the parliamencary discussion refer to the State Sector (central government). Table 18 sumarizes some statistic on the fiscal adjustment in the state sector. While the trends of general revenues and expenditures are similar to those of the general government, an important observation concerns the composition of the

1/ See Alesina, Marè, and Perotti (1996) for a discussion of the persistent bias in government's forecasts of inflation. 
Table 18. Italy: Fiscal Adjustment Central Government, 1989-95

\begin{tabular}{|c|c|c|c|c|c|}
\hline & & & & $\frac{\text { Diff. }}{.}$ & Diff. \\
\hline & 1989 & 1993 & $1994-95$ & $1994-95 / 93$ & $1994-95 / 89$ \\
\hline Revenues & 30.8 & 34.8 & 31.7 & -3.1 & 0.9 \\
\hline Expend I tures & 41.5 & 44.5 & 40.1 & -4.4 & -1.4 \\
\hline Interest payment & 8.7 & 11.7 & 10,6 & -1.1 & 1.9 \\
\hline Primary oxpenditures & 32.8 & 32.8 & 29.4 & -3.4 & -3.4 \\
\hline Hages & 5.6 & 5.7 & 5.7 & 0.0 & 0.1 \\
\hline Pensions & 1.6 & 1.9 & 2.1 & 0.2 & 0.5 \\
\hline Goods and services & 1.7 & 1.7 & 1.4 & -0.3 & -0.3 \\
\hline \multicolumn{6}{|l|}{ Iransfors to public } \\
\hline ontitias & 15.0 & 14.1 & 13.1 & -1.0 & -1.9 \\
\hline Other transfers & 4.0 & 4.7 & 4.0 & -0.7 & 0.0 \\
\hline Capital expenditures & 3.1 & 3.0 & 1.8 & -1.2 & -1.3 \\
\hline Overall balanee & -10.7 & -10.0 & -8.4 & -1.6 & -2.3 \\
\hline Primary balance & -2.0 & 1.8 & 2.3 & 0.5 & 4.3 \\
\hline
\end{tabular}

Source: IMF.

spending cuts in 1994-95. The entire cuts are on two items: capital spending and transfers to regional and municipal governments. We discussed above the likely "one off" nature of the capital spending cuts. The drastic cuts to local governments are likely to generate either some local tax increases or more creative accounting at the local level to hide liabilities. The tax autonomy of local government is currently quite limited but it is increasing. The second problem is more serious. The local health units ("unita' sanitarie locali") are a source of large hidden liabilities. Thus, these cuts in transfers to local authorities may reappear sooner or later as liabilities of the general government. I

1/ For example see Tanzi (1994) and Alesina, Marè, and Perotri (1996) for some discussion of these creative accounting practices. 


\section{b. Pension reform}

In 1995 the Italian government adopted a comprehensive reform of the pension system, one of the least solvent of the OECD. This reform, which follows a previous adjustment of 1992, replaces an income-based system with one that links benefits to contributions, although the system retains a "pay-as-you-go" nature. The reform also eliminated seniority pensions, which essentially permitted early retirement without penalties. In this paper we are only interested in the effects of this reform on the current fiscal adjustment and on its effect on long run cuts in spending.

The estimates for the budget impact of the reform in the short medium and long run are very difficult because they are based on uncertain predictions of macroeconomic and demographic variables. However even the most optimistic ones (from the Italian Treasury) suggest that the savings both in the short run and in the long run are not very large. According to the Italian Treasury, in the medium run (1995 to 2005) the reform would save about 0.4 to 0.5 percent of GDP per year, equally split between reduced spending and increased contributions. Peracchi and Rossi (1995) argue that these estimates are over optimistic because they rely on not credible forecasts. The most pessimistic estimates, form the Bank of Italy suggest that the reform may even have a negative impact on the government budget, even after the transition phase.

A recent ruling of the Constitutional Court concerning large pension arrears implies a further negative fiscal shock on the pension system. These payments will be financed with debt issues and should be about equal to the amount of savings of the pension reform as calculated by the Italian Treasury for the next five years. In summary, the effects of the reform on the budget are highly uncertain and even in the most optimistic scenarios not very large. $1 /$

\section{c. Cyclical versus discretionary adjustments} and one-off measures

After the negative growth in 1993. GNP growth in Italy was higher than forecasted both in 1994 and 1995, 2.2 against a forecast of 1.4 and 3.2 against a forecast of 2.5 percent. An interesting question is how much of the adjustment of 1994-95 was purely a cyclical phenomenon or was a result of discretionary measures. Furthermore, it is obviously important to disentangle which of the discretionary measures have a one off character and

1) Concerning the short term fiscal adjustment, one of the problems of the reform is the widely acknowledged very slow phase in period. IMF staff calculations suggest that several relatively simple and politically feasible measures to accelerate the phase in period could lead to additional savings of about . 50 percent of GDP in 1995 and slightly more in the following year. Although not huge, this amount is far from trivial: it is larger than the actual cuts in social securicy occurred in 1994-95. 
which ones are more permanent. Quite apart from the difficulties in calculating cyclical adjustments, discussed in Section III, in the case of Italy an important consideration is the baseline against which the adjustment is measured.

Typically, the Italian authorities make a comparison between the actual budget of the state sector with the "bilancio tendenziale" that is, with the budget at "unchanged legislation." Using this procedure, in 1995 an impressive 2.4 percent of GDP is the improvement of the primary balance, which arises from discretionary fiscal measures. One problem with these calculations is that the criteria for the computation of the "bilancio tendenziale" are obscure and depend on possibly questionable assumptions. A more useful comparison is between the primary budget surplus of the State Sector in 1995 relative to the surplus in 1994. According to the IMF staff calculations, of the 2.4 increase in the primary surplus between these two years, only .8 percent of GNP can be attributed to permanent discretionary measures. The remaining 1.6 percent is about equally split between the effect of higher than forecasted growth and inflation and one off measures.

Unfortunately, similar calculations are not available for previous years and for the general government. However as far as 1995 is concerned, the effect of the cycle and of one off measures should have the same order of magnitude as for the state sector. Thus, when closely examined only a small fraction of the 1995 improvement in the fiscal balance has a permanent nature. $1 /$

\section{d. Contractionary or expansionary adjustment?}

Table 19 clearly shows that the Italian fiscal adjustment is associated with strong contractionary consequences on domestic demand, while the external sectors contained the negative effect of domestic demand on growth. The Italian growth rate shows a declining trend from 4.1 per in 1988 to -.7 in 1993. In the period 1989-94 the Italian growth rate is on average, 0.7 percent below the $G-7$ average. As shown in Table 19 , private investment literally collapsed in this period: in 1993 it fell by about 18 percent! This development is in sharp contrast with the case of Ireland and Denmark, where private investment boomed during the adjustment. Growth in private consumption was very sluggish and turned negative in 1993. At least until 1993 there is no sign that interest rates incorporated a "credibility gain bonus." The only "good news" for the economy in the period 1989-93 is the reduction in unit labor costs, as shown in Table 19. In summary, until 1993 the Italian adjustment has all the features of a contractionary adjustment, all driven by tax increases, without spending cuts.

1/ This is why in Tables 16 and 17 we focus on an average of 1994 and 1995, which gives a better picture of the recent trend in the adjustment, rather than focusing on 1995, which for many reasons discussed above, appears as a rather "lucky" year. 
The recent developments of $1994-95$ are also quite instructive. The recession of 1993 was contained by a growth of almost 9 percent in export volume. The rate of growth in $1994-95$ was also almost exclusively driven by the export sector. In 1994 and 1995 export volume grew at 10.7 and 13.6. respectively, with a trade surplus of about 4 percent of GNP. These external developments were driven mostly by the large real devaluation of the exchange rate, equal to about 25 percent from September 1992 when the lira abandoned the EMS. A second factor influencing competitiveness was the relative wage moderation achieved after 1993. Note that this wage moderation. coincided with the end of major tax increases. All the measure of competitiveness indicate substantial gains for Italy in the last three years, of the order of 20 percent, the largest amount in the OECD together with Sweden.

The pattern of consumer confidence (Chart 1) closely follows the cycle. Consumer confidence was very low during the recession of 1993 and bounced back with the recovery of 1994. Despite the higher than expected growth of 1995, consumer confidence is slightly lower at the end of 1995 than in 1994. It is difficult to see any significant effect of the fiscal adjustment on consumer confidence.

Interest rate differential relative to Germany fell in 1993 from more than 6 percent on 10-year government bonds to less than 3 percent at the end of the year. By the beginning of 1995 this differential was back at almost 5 percent. The differential on 3 -month treasury bills is about 4 percent, the same level as at the beginning of 1993. This pattern indicates that the market has doubts about the credibility and persistence of the fiscal adjustment even after the 1994-95 spending cuts. This behavior of interest rate differential is in sharp contrast with the Danish and Irish experience.

This evidence clearly points toward a clear conclusion: not only the 1989-93 fiscal adjustment negatively affected private demand, but the 1994-95 adjustment had the same effect and would have had negative growth consequences if it had not been accompanied by a massive depreciation of the real exchange rate. In summary, until 1993 the Italian adjustment is certainly of "Type 2". Some of the spending cuts in 1995 seem to appear as a "Type 1" adjustment, but are too plagued by "one off" measures and are of uncertain duration.

\section{vI. Conclusion}

The single most important idea that we hope the reader will remember from this paper is that the composition of fiscal adjustments matters for their likelihood of success and for their macroeconomic consequences. In our view, the academic literature focuses too much on aggregate models which disregard composition and distributional effects. Also, the emphasis of the Maastricht criteria has shifted the discussion too much toward simple arithmetics of primary surpluses, deficits and debt to GDP ratios and away from "how" one cuts deficits to meet these criteria, as if the "how" didn't really matter. Instead, it does. 
Table 19. Italy: Macroeconomic Conditions and the Fiscal Adjustment, $1989-94$

\begin{tabular}{lccc}
\hline & $\begin{array}{c}\text { Before } \\
(1)\end{array}$ & $\begin{array}{c}\text { During } \\
(2)\end{array}$ & $\begin{array}{c}\text { Diff } \\
(2)-(1)\end{array}$ \\
\hline GR (G-7) & 0.21 & -0.70 & -0.91 \\
U (G-7) & 6.60 & 5.63 & -0.97 \\
$\Delta I$ & 10.6 & -1.50 & -12.10 \\
$\Delta C$ & 4.1 & 1.49 & -2.61 \\
i (G-7) & 3.03 & 5.13 & 2.10 \\
F (G-7) & 0.57 & 2.66 & 2.09 \\
ULC & 5.16 & -2.25 & \\
EXCH RATE & -1.76 & -3.13 & 1.04 \\
TB & -0.44 & 0.60 & 0.07 \\
WSH & 44.40 & 44.47 & -0.99 \\
PSH & 38.60 & 37.61 & \\
\hline
\end{tabular}

Source: OECD. For a definition of the variables see Table 10 .

Rather than reviewing in detail our results we conclude by discussing several open issues for further research:

(i) A fair amount of evidence suggests that, in some cases, fiscal contractions can be expansionary. An important question is through which channel. We have argued that models which emphasize the effect of the composition of the adjustment on unit labor costs in unionized and open economies are at least as relevant empirically as models which focus upon credibility and wealth effects. This argument needs a more thorough empirical investigation.

(ii) Even though we have made some steps toward linking the composition of the budget to its macroeconomic effects, one should disaggregate more the government accounts. For instance, our variable "transfers" which is quice important for our argument, is still quite 
Chart 1

HOUSEHOLD CONFIDENCE INDEX (1)

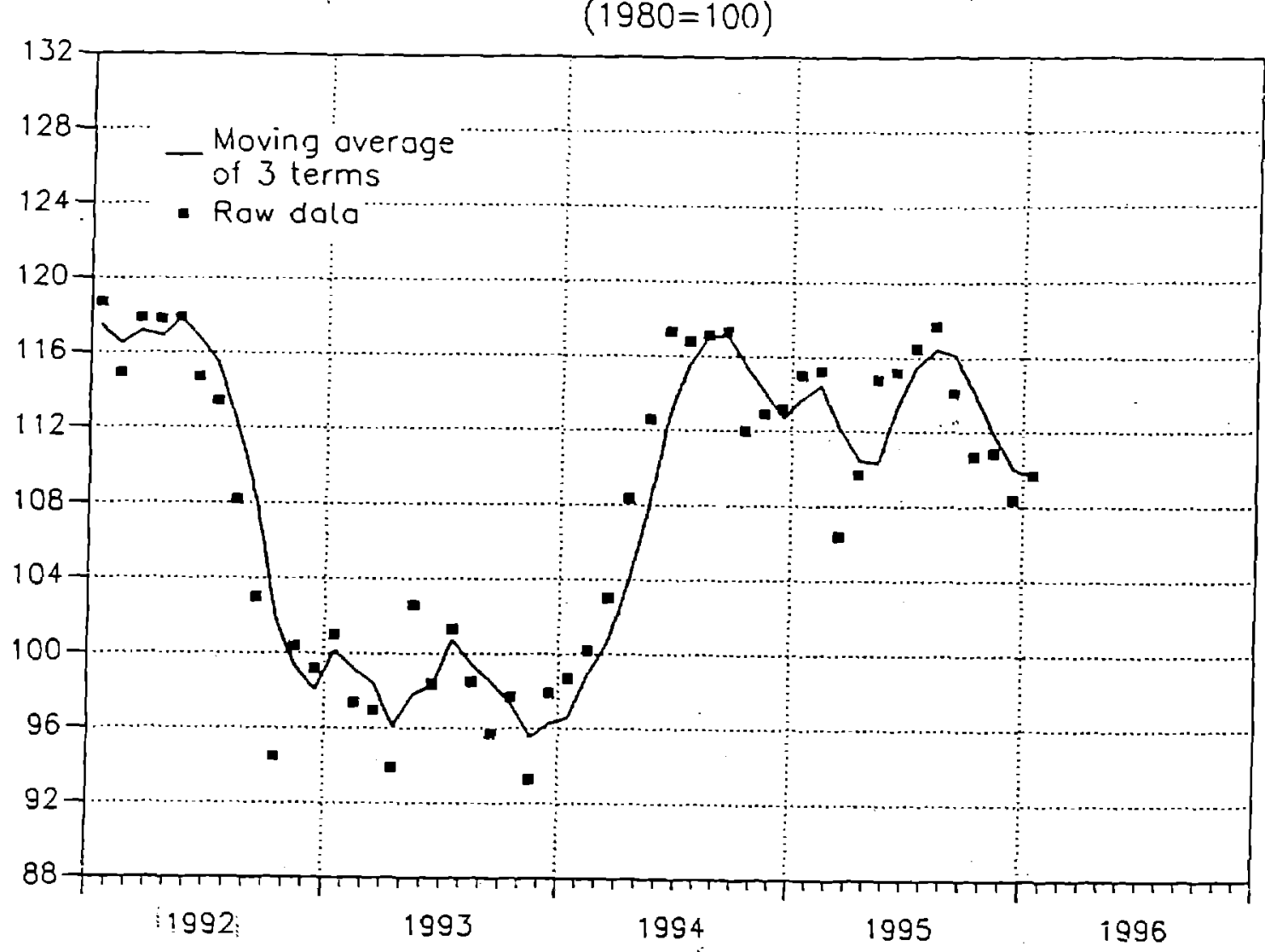

Sources: Based on Isco dota.

(1) Doto for August computed as overage of July and September figures until 1994. 
aggregate and includes social security, unemployment compensation, other social assistance programs, etc. A more disaggregate study in a multicountry sample should clarify which components of the "transfers" variable are more important in determining the success or failure of adjustments.

(iii) A very important policy decision concerns the policy mix which should accompany a major fiscal adjustment, particularly the exchange rate policy. Several major successful adjustments have been preceded by devaluations, but the same happened for some of the unsuccessful ones. The question is whether a devaluation helps in determining the success of the adjustment and its macroeconomic consequences. We have hinted in our paper that a devaluation may help, but it would not "do the trick" if the composition of the adjustment did not have the features which we have discussed at length. Further research on this topic not only is fascinating from an academic perspective but has important policy implications. For example, this issue has critical implications for the effects of fiscal adjustments before or after a monetary union.

(iv) In our statistical analysis of the sample of OECD countries we focused on the general government. An intriguing issue is the role of local governments during major fiscal adjustments. Are the adjustments typically carried trough the central government? How do local governments participate in the effort? Is there a shifting of responsibility between the two layers of government? Hints in the discussion of the Italian case suggest that this might be an important area worth exploring.

(v) Finally, one may wonder why policymakers are often hesitant in engaging in vigorous fiscal adjustments of "Type 1," considering that they do not seem to have contractionary effects. Perhaps the answer lies in their distributional effects. We hinted above that the functional distribution of income is tilted in favor of profits during successful adjustments. A more careful study of the distributional consequences of major fiscal adjustments is an excellent topic of research.

In summary, the efforts toward fiscal adjustment that several OECD countries are currently facing is strictly linked to the problem of reforming the welfare state, whose weight has been increasing in the last few decades. Any fiscal adjustment that avoids dealing with the problems of social security, welfare programs and inflated government bureaucracies is doomed to failure. 


\section{Definition of Variables}

\section{Fiscal variables}

All variables used are from $O E C D$, unless otherwise indicated in the text.

TRANSFERS - Social security benefits + social assistance grants + unfunded employee pension and welfare benefits + transfers to the rest of the world + transfers to private nonprofit institutions serving households + net casualty insurance premiums + other transfers.

PUBLIC INVESTMENT - Government cross fixed capital formation: The outlays, purchases and own-account production of producers of government services on additions of new durable goods (commodities) to their stocks of fixed assets... Excluded are the outlays of government services on durable goods for military use.

GOVERNMENT CONSUMPTION (divided into its wage component and nonwage component) - The value of goods and services produced for their own use on current account, that is the value of their gross output less the sum of the value of their commodity and noncommodity sales and the value of their ownaccount capital formation which is not segregated to an industry. The value of their gross output is equal to the sum of their intermediate consumption of goods and services, compensation of employees, consumption of fixed capital and indirect taxes.

SUBSIDIES: All grants on current account made by government to private industries and public corporations.

DIRECT TAXES ON INCOME: Levies by public authorities at regular intervals, except social security contributions, on income from employment, property, capital gains, or any other source.

INDIRECT TAXES: Taxes assessed on producers in respect of their production, sale, purchase, or use of goods and services, which they charge to the expenses of production. Also included are import duties and the operating surplus, reduced by the normal margin of profits of business units, of fiscal and similar monopolies of government.

SOCIAL SECURITY CONTRIBUTIONS: Social security contributions received by government.

For a more detailed discussion concerning the construction of a measure of primary deficit and the cyclical adjustment, see the appendix of Alesina and Perotti (1995a). 


\section{Other variables}

GR $(G-7)$ - (yearly rate of GDP growth of each country year) - (average GDP growth of G-7 countries with GDP weights)

$U(G-7)$ - (unemployment rate of each country year) - (average unemployment of G-7 countries with GDP weights)

$\Delta I$ - rate of growth of private business investment

$\Delta C=$ rate of growth of private consumption

i $(G-7)$ - (nominal interest rate on 10 -year government bonds) (average nominal interest rate on 10 -year government bonds in $G-7$ countries with GDP weights)

r (G-7) - (nominal interest rate on 10 -year government bonds inflation) - (average real interest rate in $G-7$ countries with GDP weight). The real interest rate in each of the $G-7$ countries is obtained as the nominal rate minus inflation.

ULC = rate of change of unit labor costs in manufacturing, as calculated by Alesina and Perotti (1994) on OECD data.

EXCH RATE - rate of change of the nominal effective exchange rate

VAULC - rate of change of the value added deflator over unit labor costs in manufacturing.

WSH = wage share.

PSH = profit share. 


\section{$\underline{\text { References }}$}

Alesina, A. and A. Drazen, 1991, "Why are Stabilizations Delayed?" American Economic Review, December.

Alesina, A., M. Marè, and R. Perotti, 1996, "Le Procedure di Bilancio in Italia: Analisi e Proposte," unpublished.

Alesina, A. and R. Perotti, 1994, "The Welfare State and Competitiveness," NBER Working Paper No. 4810.

1995a "Fiscal Expansions and Adjustments in OECD Countries," Economic Policy, 21, pp. 207-248.

, 1995b, "Taxation and Redistribution in an Open Economy," European Economic Review, May, pp. 961-980.

, 1996, "Reducing Budget Deficits," Swedish Economic Policy Review, for thcoming.

Bank of Italy, 1996, Bollettino Economico, n. 26, Rome, Italy.

Barro, R., 1981 "Output Effects of Government Purchases," Journal of Political Economy, 89, December, Pp. 1086-1121.

1989, "The Neoclassical Approach to Fiscal Policy," in R. Barro (ed.), Modern Business Cycle Theory, Harvard University Press, Cambridge, Massachusetts, pp. 178-235.

Baxter, M., 1993, "Financial Market Linkages and the International Transmission of Fiscal Policy," University of Rochester, mimeo. and R. King, 1993, "Fiscal Policy in General Equilibrium, American Economic Review, Vo1. 83, No. 3, Pp. 315-334.

Bertola, G. and A. Drazen, 1993, "Trigger Points and Budget Cuts: Explaining the Effects of Fiscal Austerity," American Economic Review, 83, pp. 11-26.

Blanchard, 0., 1985, "Debt, Deficits, and Finite Horizons," Journal of Political Economy, 93, pp. 223-247.

, 1990, "Comments on Giavazzi and Pagano," in Olivier Blanchard and Stanley Fischer, eds., NBER Macroeconomics Annual 1990, Cambridge, MA, MIT Press, pp. 110-117.

_. 1993, "Suggestions for a New Set of Fiscal Indicators," unpublished.

Bohn, H., 1991, "Budget Balance Through Revenue or Spending Adjustments?" Journal of Monetary Economics.

Bruno, M. and J. Sachs, 1985, The Economics of Worldwide Stagflation, Oxford, U.K., Basil Blackwell. 
Buiter, W., 1983, "Measurement of the Public Sector Deficit and Its Implications for Policy Evaluation and Design," IMF Staff Papers. , 1985, "A Guide to Public Sector Deficits," Economic Policy.

Calmfors, L. and J. Driffill, 1988, "Bargaining Structure, Corporatism, and Macroeconomic Performance," Economic Policy, No. 6, April, pp. 13-62.

Chouraqui, J.C., R. Hagemann, and N. Sartor, 1990, "Indicators of Fiscal Policy, a Reassessment," OECD Working Paper.

de Haan, J., G. Sterks, and C. de Kam, 1992, "Toward Budget Discipline: An Economic Assessment of the Possibilities for Reducing National Deficits in the Transition to EMU," EEC Economic Papers.

Dornsbusch, R. 1989, "Credibility Debt and Unemployment: Ireland's Failed Stabilization," Economic Policy.

Drazen, A. and V. Grilli, 1993, "The Benefits of Crises for Economic Reforms," American Economic Review, Vol. 83, No. 3, pp. 598-607.

Giavazzi, F. and M. Pagano, 1990, "Can Severe Fiscal Adjustments be Expansionary?" NBER Macroeconomic Annual, pp. 75-122.

1996, "Non-Keynesian Effects of Fiscal Policy Changes: International Evidence and the Swedish Experience," Swedish Economic Policy Review, forthcoming.

Grilli, V., D. Masciandaro, and G. Tabellini, 1991, "Political Monetary Institutions and Public Finance Policies in the Industrial Democracies," Economic Policy.

Lane, P. and R. Perotti, 1995, "Profitability, Fiscal Policy, and Exchange Rate Regimes," mimeo, Harvard University.

Lindbeck, A., 1994, "Overshooting, Reform and Retreat of the Welfare State," De Economist, Vol. 142, No. 1, pp. 1-19.

McDermott, J. and R. Wescott, 1996, "The Economics of Fiscal Consolidation," IMF, unpublished draft.

McKenzie, G., 1988, "Are All Summary Indicators of Stance of Fiscal Policy Misleading?" IMF Staff Papers.

Miller, M., R. Sidelsky, and P. Weller, 1990, "Fear of Deficit Financing: Is It Rational?" in R. Dornbusch and M. Draghi (ed.), Public Debt Management: Theory and History, Cambridge, MA, Cambridge University Press.

Pencavel, J., 1986, "Labor Supply of Men: A Survey," in O. Ashenfelter and R. Layard Handbook of Labor Economics, North Holland, Amsterdam. 
Perotti, R., 1996a, "Fiscal Consolidation in Europe: Composition Matters," American Economic Review, Papers and Proceedings, forthcoming. , 1996b, "Do We Know How to Estimate Discretionary Fiscal Policy?", mimeo, Columbia University.

Roubini, N. and J. Sachs, 1989, "Political and Economic Determinants of Budget Deficits in the Industrial Democracies, "European Economic Review.

Spolaore, E., 1993, "Policy Making Systems and Economic Efficiency: Coalition Governments versus Majority Governments," unpublished.

Sutherland, A., 1995, "Fiscal Crises and Aggregate Demand: Can High Public Debt Reverse the Effect of Fiscal Policy?" CEPR Working Paper.

Tanz1, V., 1994, "International Systems of Public Expenditure Auditing: Lessons for Italy," from the proceeding of the conference "Nuovo Sistema di Controllo Sulla Spesa Pubblica," Bank of Italy, Rome.

Tanzi, V. and L. Schuknecht, 1995, "The Growth of Government and the Reform of the State in Industrial Countries," IMF Working Paper, December.

Velasco, A., 1996, "A Model of Fiscal Deficits and Delayed Fiscal Reforms," mimeo, New York University. 